Examining and

Grading Grains

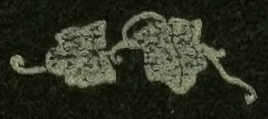




\section{Examining and Grading}

\section{Grains}

BY

T. L. LYON, Рн. D.

Professor of Agriculture

Universily of Nebraska

AND

E. G. MONTGOMERY

Assistant in Field Crops

University of Nobraska 


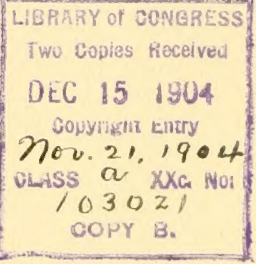

COPYRIGHTED, 1904

BY THE AUTHORS

$\because \vdots \vdots$ 


\section{CONTENTS.}

PAGE

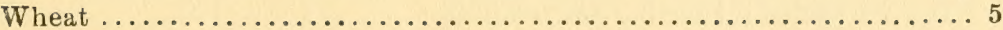

Classification of species and varieties.................... 5

Laboratory study of characters...... ................ 6

Terms for describing characters...................... 8

Outline for describing wheats...............................

Examining and grading wheat........................... 16

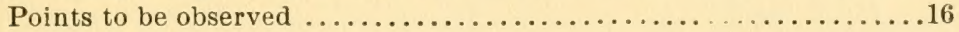

Hardness, texture, weight, soundness, mustiness, color.......16-18

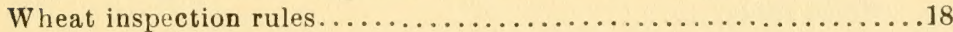

Testing wheat for purity.... . . . . . . . . . . . . . . . 20

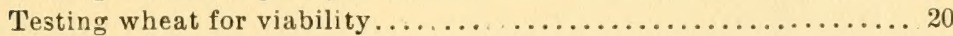

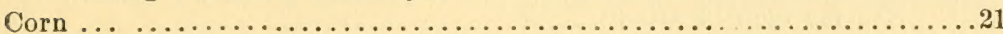

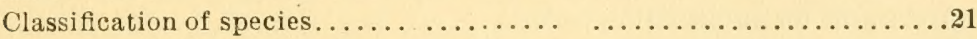

Laboratory study of species and of characters.................22

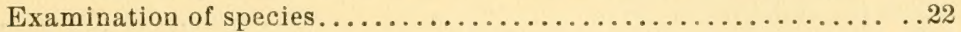

Terms for describing characters.......................... 23

Outline for describing corn .................................

Outline for comparing variety types.................. 27

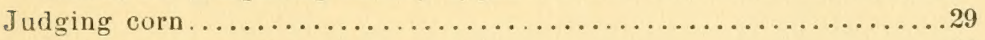

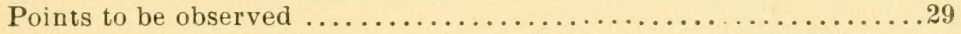

Uniformity of exhibit, shape of ears, color of cobs, color of kernels, market condition, tips of ears, butts of ears, uniformity of kernels, shape of kernels, space between kernels, proportion of

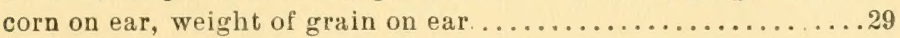

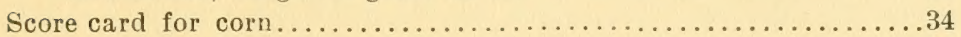

Rules for judging exhibits of corn ..........................

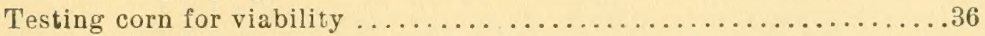

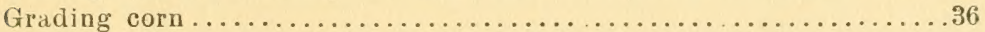

Points to be observed...................................

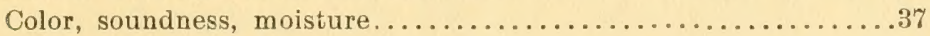

Corn inspection rules. . . . . . . . . . . . . . . . . . . . . . . 38

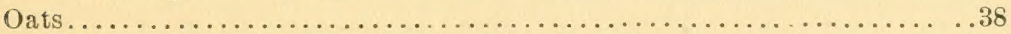

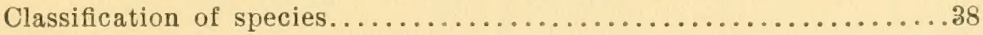

Laboratory study of characters............................ 40

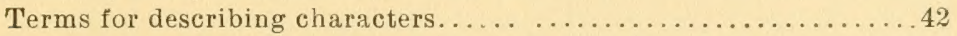

Outline for describing oats........................ 45

Examining and grading oats............................ 45

Points to be observed.......................................

Mustiness, purity, plumpness, soundness, weight.........45-46

Oat inspection rules............................... 46

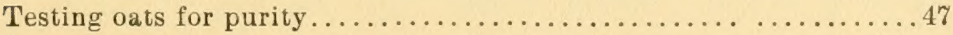


Testing oats for viability ............................. 47

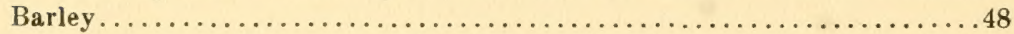

Classification of species and varieties...................... 48

Terms for describing characters................... 50

Outline for describing barleys...................... 54

Examining and grading barley ........................ 54

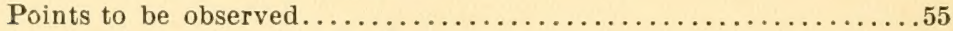

Color, texture, brewing qualities.................... 55

Barley inspection rules. . . . . . . . . . . . . . . . . . 56

Testing barley for purity and viability $\ldots \ldots \ldots \ldots \ldots \ldots \ldots \ldots \ldots$

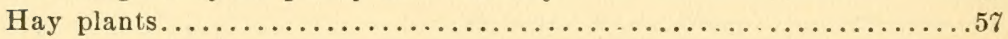

Outline for describing grasses......................... 57

Examination of grass seeds............................. 57

Hay and straw inspection rules........................ 58

Identification of clover and grass seeds................... 59

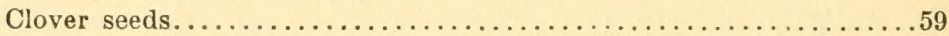

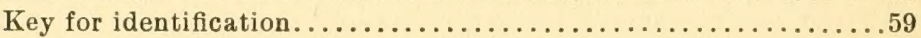

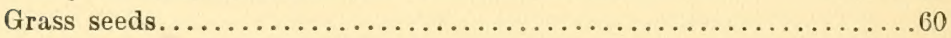

Key for identification........................... 60

Millet seed......................................61

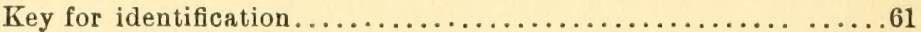

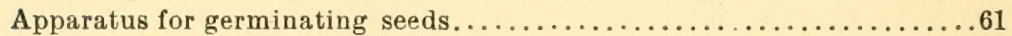

Determination of weight per bushel......................62

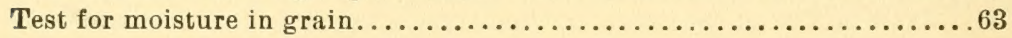

Table of grain weights per bushel............................. 


\section{WHEAT}

\section{CLASSIFICATION OF SPECIES AND VARIETIES.}

The wheats are classified into several species and varieties, founded on distinct differences.

Wheat belongs to the family of plants known as the Gramineae which includes all of our cereal crops and meadow grasses.

All of these plants are readily distinguished by having only one seed leaf and are technically known as monocotyledons.

Wheats seem to be most properly classified into species and races, as follows:

Triticum monococcum (one grained wheat), spikes compact, spikelets 3 flowered but 1 grained, bearded. Very old, belongs to Stone age, grown in Spain, Germany, Switzerland. Not much of a bread wheat.

Triticum Polonicum (Polish wheat), large, open heads, spikelets 2 to 3 seeded, bearded. Seeds long, bright and glossy. Cultivated in parts of Eastern Europe and Northern Africa.

Triticum sativum, divided into races, as follows:

Tr. sat. vulgare (common wheat), 4 flowered spikelets, 3 grained, both bearded and beardless. Our common bread wheats, many varieties, almost exclusively grown in this country.

Tr. sat. compactum ("Hedgehog wheat," "Dwarf wheat"), spikes short, dense, distinctly 4 sided, both bearded and beardless. Grown in Switzerland and neighboring region, also in Turkestan and Chili.

Tr. sat. turgidum ("English wheat," "Egyptian wheat"), spikes large, dense, 4 sided, 2 to 3 seeded, 
bearded. Largely grown in Mediterranean countries, also in Egypt, England and Germany.

Tr. sat. durum (True bearded, or Hard wheats), spikelets 3 to 4 seeded, long stiff awns; seeds large, bright and glossy. This race comprises the so-called Macaroni wheats which are at present being extensively tested in the semi-arid portions of the country. They are widely grown in Eastern Europe and Northern Africa.

Tr. sat. Spelta (Spelt), spikes long and very loose, darkish colored when ripe, spikelets 3 seeded at base, 2 at top of spike. Chaff adheres to grain. Little grown in this country. At home in the mountain regions of Europe and Asia.

Tr. sat. dicoccum (Emmer), spikelets 2 seeded, rather compactly arranged in 2 rows, generally dark colored, grain very hard, enclosed in chaff. Little grown in this country. More common in Central Europe.

The varieties of Triticum durum, commonly known as "Macaroni wheats" because of the excellent quality for the manufacture of macaroni and similar pastes, are considered very hardy and drought-resistant and give promise of becoming valuable wheats for the semi-arid regions of this country.

Emmer ( $T$. dicoccum), commonly confused with spelt, also gives promise of a wider usefulness.

Of these wheats we are principally concerned with the varieties of Triticum Sativum vulgare.

\section{LABORATORY STUDY OF CHARACTERS.}

In the study of wheats in the head, specimens of several varieties should be examined, including specimens of the four principal types of wheat, viz., Triticum vuigare; T. durum; T. spelta, and T. Polonicum. 


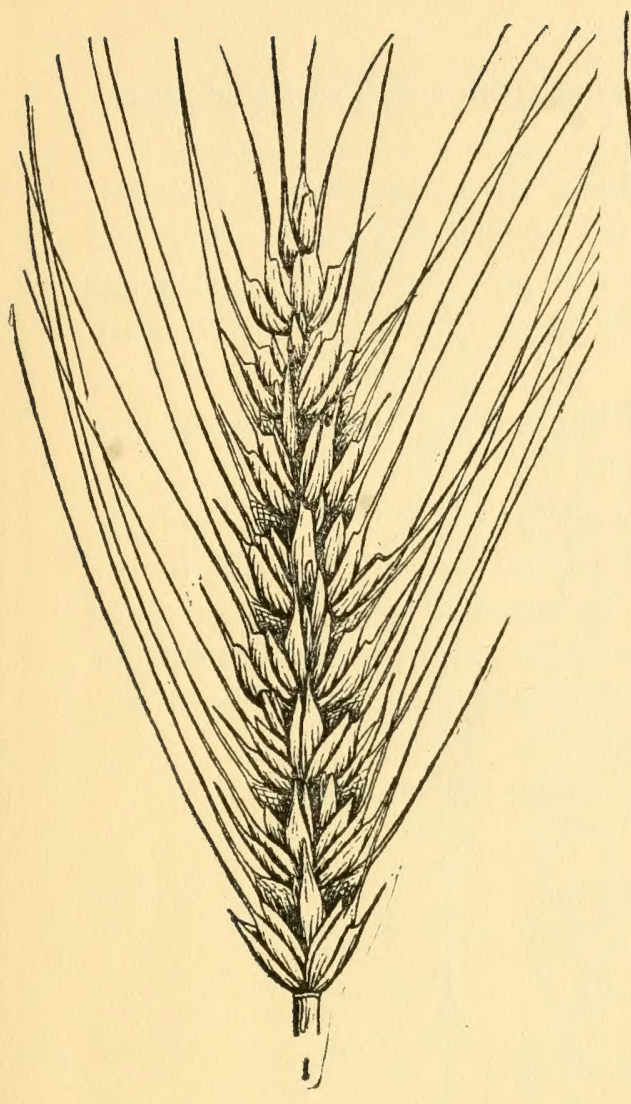

\section{Plate 1}

The above cut shows a spike of ordinary wheat. On the right a single spikelet is first shown. Below this the spikelet is torn into its several parts and each part named.

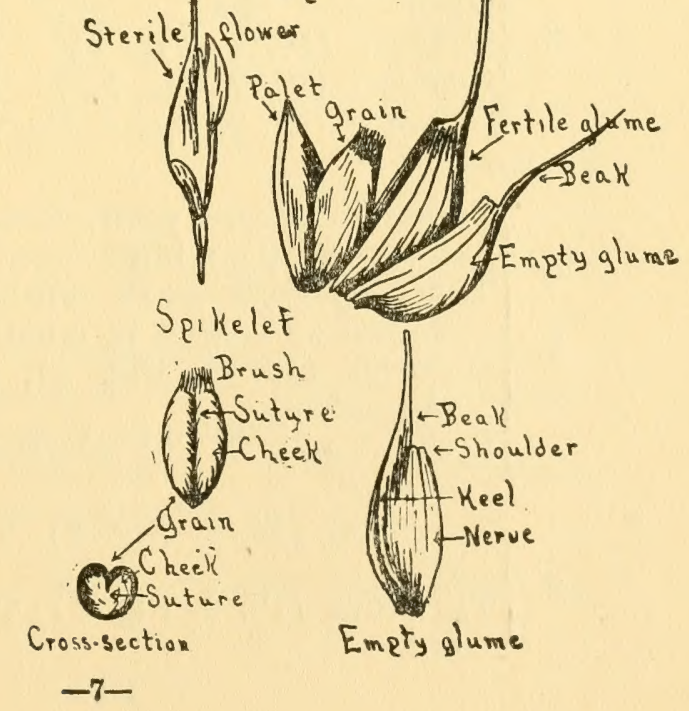


Drawings: Make a drawing from a spike of each of the four types as follows:

First, the spike as a whole, then removing a spikelet, draw this entire, showing the embricated view. Then dissect the spikelet, drawing each part out separately, being careful to arrange the parts in their proper relative position.

The method of cross-fertilizing wheats may now be easily explained by the teacher.

The Wheat Spike and Descriptive Terms. The following is a list of descriptive adjectives which apply to the wheat head. The student is supplied with two or three heads of the wheat to be described, and proceeds to fill out the blank used in describing wheats, using the list of descriptive terms as a reference:

\section{SPIKE}

TERMS FOR DESCRIBING CHARACTERS

$$
\text { 1. }\left\{\begin{array}{l}
\text { Beardless (Pl. 2, Fig. 3) } \\
\text { Partly bearded (Pl. 2, Fig. 4) } \\
\text { Bearded (Pl. 2, Fig. 2) }
\end{array}\right\}
$$

2. Length, inches

\section{Shape}

3. $\left\{\begin{array}{l}\text { Very open (Pl. 2, Fig. 3) } \\ \text { Open } \\ \text { Medium (Pl. 1, Fig. 1) } \\ \text { Compact (Pl. 2, Fig. 1) } \\ \text { Crowded (Pl. 2, Fig. 4, tip) }\end{array}\right\} \begin{aligned} & \text { Refers to how closely the } \\ & \text { spikelets are set together. }\end{aligned}$

Tapering toward apex, Heads which taper gradually from the middle toward the tip.

Tapering both ways, Heads which are spindle

1. shaped or largest in middle.

Uniform (Pl. 2, Fig. 1), Heads same diameter throughout.

Clubbed (Pl. 2, Fig. 4), Heads larger at tip than below.

Tip acute (P1. 2, Fig. 2), Tip spikelets not devel-

2. $\{$ oped.

Tip blunt (Pl. 2, Fig. 4), Tip spikelets well filled out. 
(Base abrupt (P1. 2, Fig. 2), Basal spikelets well 3. $\{$ developed.

Base tapering, Basal spikelets not well developed.
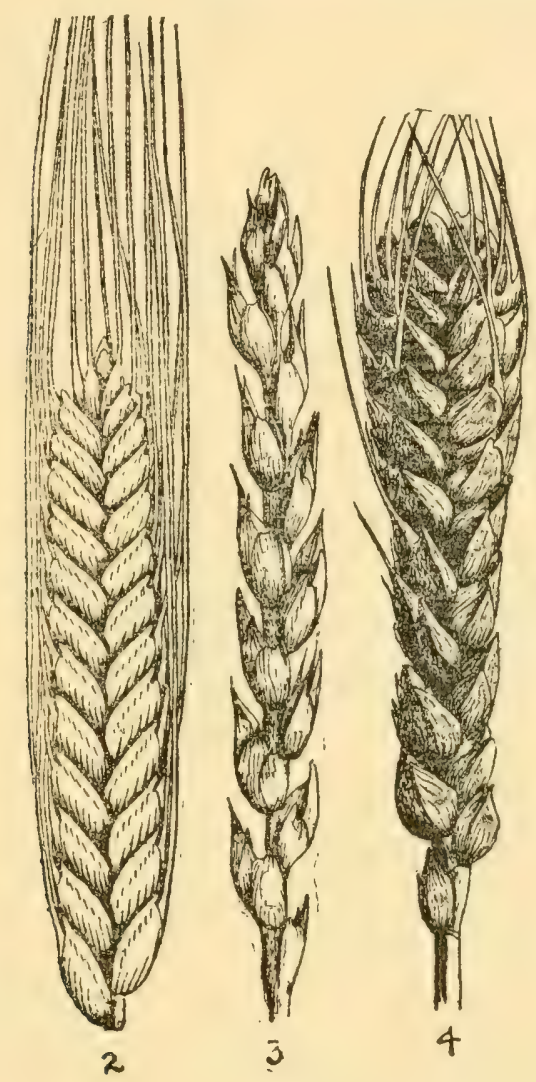

Plate 2

Three types of wheat heads. No. 2, macaroni wheat; No. 3, a common type of bald wheat; No. 4, club wheat.

(Square. Refers to cross-section.

|Flattened with spikelets (Pl. 1, Fig. 1). Diameter

4. $\{$ of head through spikelets least.

Flattened across spikelets (Pl. 2, Fig. 2), Diameter (through spikelets greatest.

5. $\{$ Sterile spikelets, $1,2,3,4$. Sterile spikelets at tip I and base of spike. 
Color

1. $\left\{\begin{array}{l}\text { Whitish } \\ \text { Yellow } \\ \text { Yellowish brown } \\ \text { Red } \\ \text { Bluish } \\ \text { Brown } \\ \text { Black }\end{array}\right.$

AWNS

1. $\left\{\begin{array}{l}\text { Long, } 4 \text { in. or more in length. } \\ \text { Medium, } 2 \text { in. to } 4 \text { in. in length. } \\ \text { Short, } 2 \text { in. or less in length. }\end{array}\right.$

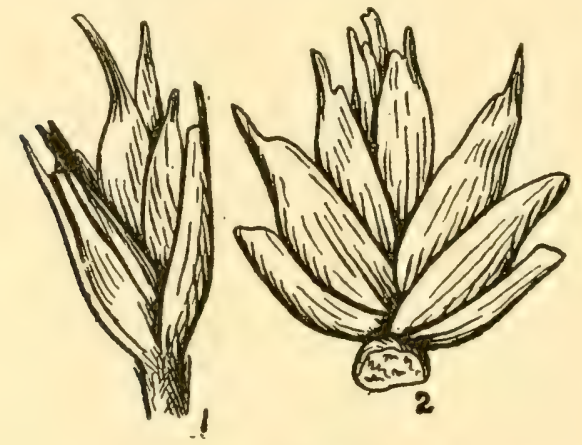

Plate 3

Two types of wheat spikelets.

2. $\left\{\begin{array}{l}\text { Parallel (Pl. 2, Fig. 2) } \\ \text { Spreading } \\ \text { Spreading widely (Pl. 1, Fig. 1) }\end{array}\right\} \begin{aligned} & \text { Has reference to the } \\ & \text { relative position of } \\ & \text { awns and spike. }\end{aligned}$

Deciduous. Awus falling as soon as grain is mature.

3. $\{$ Partly deciduous $\}$

(Persistent. Awns not falling off naturally.

Color
Whitish
1. Brownish
Yellow Black

\section{SPIKELET}

\footnotetext{
(Spreading widely (Pl. 3, Fig. 2) Refers to the relative

1. $\{$ Spreading $\} \begin{gathered}\text { width of the spike- } \\ \text { with }\end{gathered}$

Narrow (Pl. 3, Fig. 1)

let.

2. Number of grains, $1,2,3,4,5,6,7$. 
Outer glume

(Hairy (Pl. 5, Figs. 2 and 3)

1. Partly hairy

(Smooth (Pl. 5, Figs. 1 and 4)

2. Glossy

IDull

3. $\left\{\begin{array}{l}\text { Uniform in color } \\ \text { Streaked }\end{array}\right.$

Size

1. Broad (Pl. 4, Fig. 2) Tefers to the general shape of 1. Medium $\}$ of the glume, and the way it [Narrow (Pl. 4, Fig. 1) \} fits about the grain.
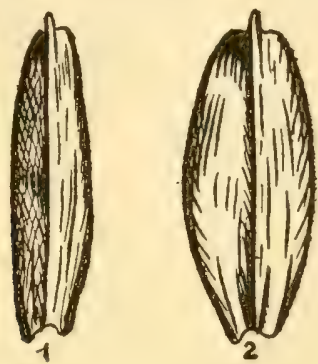

Plate 4

Wide and narrow outer glumes

2. $\left\{\begin{array}{l}\text { Short } \\ \text { Long }\end{array}\right\}$

In comparison with rest of spikelet.

Attachment

1. $\left\{\begin{array}{l}\text { Firm } \\ \text { Weak }\end{array}\right.$

Keel 1. $\left\{\begin{array}{l}\text { Broad } \\ \text { Medium }\end{array}\right\} \quad \begin{gathered}\text { The keel is the central nerve, most prominent in } \\ \text { varieties of } T . \text { Durum. }\end{gathered}$ Beak [Narrow

1. $\left\{\begin{array}{l}\text { Long (Pl. 5, Fig. 3) } \\ \text { Medium } \\ \text { Short (Pl. 5, Fig. 1) }\end{array}\right\}$

The beak is the extended midrid of the empty glume, which, on

2. $\{$ Acute (Pl. 5, Fig. 3) $\}$ the flowering glume when more extended, is called an awn.

(Blunt (Pl. 5, Fig. 2) 
Shoulder

1. $\{$ Broad (Pl. 5, Fig. 3)

(Narrow (Pl. 5, Fig. 1)

S Square (P1. 5, Fig. 3)

2. Sloping (Pl. 5, Fig. 1)

llound (Pl. 5, Fig. 2)

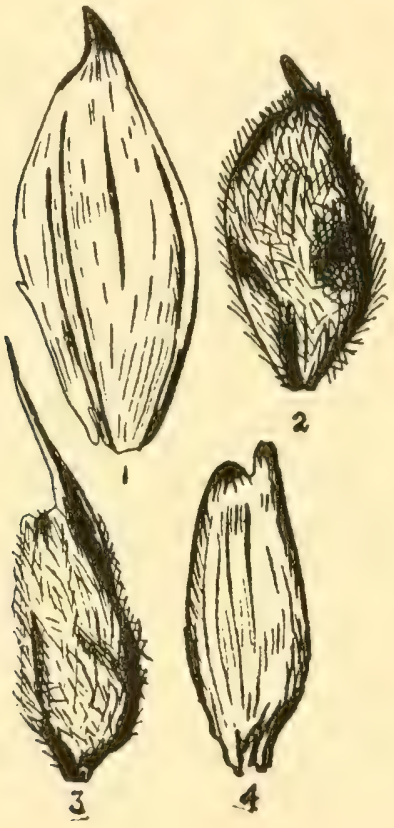

Plate 5

Types of outer glumes, showing typical beaks and shoulders.

\section{GRAIN}

1. $\left\{\begin{array}{l}\text { Very hard } \\ \text { Hard } \\ \text { Medium } \\ \text { Soft } \\ \text { Very soft }\end{array}\right\}$

Size
This point is determined by biting or cutting open several grains and oomparing with standard samples.

Wt. 100 av. seeds, grams..... 
Shape

(Long (Pl. 6, Fig. 3)

Medium

1. Short (PI. 6, Fig. 2)

Curved (Pl. 6, Fig. 1)

Straight

(Pear-shaped (Pl. 6, Fig. 5)

2. $\left\{\begin{array}{l}\text { Thin } \\ \text { Medium } \\ \text { Plump }\end{array}\right.$

(Flat-cheeked (Pl. 6, Fig. 7)

3. Plump-cheeked (Pl. 6, Fig. 8)

Angular-cheeked (Pl. 6, Fig. 9)

4. $\left\{\begin{array}{l}\text { Pointed at tip } \\ \text { Blunt at tip }\end{array}\right.$

5. $\left\{\begin{array}{l}\text { Pointed at base } \\ \text { Blunt at base }\end{array}\right.$
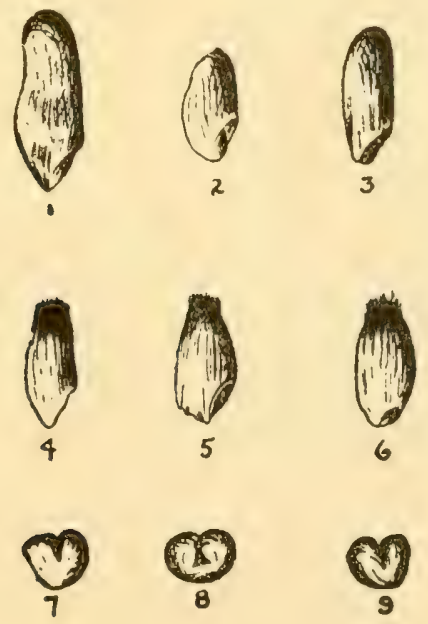

\section{Plate 6}

Types of wheat grains and cross sections. 
Color
$\left\{\begin{array}{l}\text { Whitish } \\ \text { Yellowish }\end{array}\right.$
1. $\{$ Clear amber
Dull amber
Clear red
¿Dull red

\section{Crease}
1. $\left\{\begin{array}{l}\text { Deep } \\ \text { Medium } \\ \text { Shallow }\end{array}\right.$
2. $\left\{\begin{array}{l}\text { Wide } \\ \text { Medium } \\ \text { Narrow }\end{array}\right.$

(Make cross section and compare.)

\section{Cross-section}
1. $\left\{\begin{array}{l}\text { Very horny } \\ \text { Horny } \\ \text { Dull } \\ \text { Starchy }\end{array}\right.$
Refers to appearance. When the grain in cross-section is hard and vitreous in texture, it is "very horny," but when there is no horny portion, but the cross.section is all white and starchy in appearance, it is called "starchy,"

GENERAL CHARACTERISTICS
1. Delicate Carly
2. Medium Late

3. Days maturing 4. $\left\{\begin{array}{l}\text { Autumn-planted } \\ \text { Spring-planted }\end{array}\right\}$
These points can only be determined by referring to field notes on the variety. 
OUTLINE FOR DESCRIBING WHEAT

Variety Name. SPIKE

1

2

3

Shape

1.

2

3

4

5

Color

1

AWNS

1

2

3

Color

1

SPIKELET

1.

2

Outer Glume

1

2

3

Size

1

2

Attachment

1
.Number of Sample...

Keel

1

Beak

$1 \ldots \ldots \ldots \ldots \ldots \ldots$

2

Shoulder

1

2

GRAIN

1

Shape

$1 \ldots \ldots \ldots \ldots \ldots$

$2 \ldots \ldots \ldots \ldots \ldots \ldots$

3

4

5

Color

1

Crease

$1 \ldots \ldots \ldots \ldots \ldots$

2

Cross-section

1

GENERAL CHARACTERISTICS

1

2

3

4

Student's Name

.Date. . 


\section{EXAMINING AND GRADING WHEATS.}

The object of this work is not primarily to learn what constitutes a grade, but rather to give the student a knowledge, based on critical examination, of the qualities and characteristics of the common varieties and grades of wheat, both good and bad.

For this purpose, have in hand a copy of the following: "Points to be Observed in Judging Wheat" together with the "Inspection Rules."

About 25 samples are provided as before, each to be graded and examined carefully as to "Hardness", "Texture", "Weight", "Color", etc., as described in "Points to be Observed." As this course is concurrent with a course of lectures on field crops, the significance of these points should be understood.

\section{POINTS TO BE OBSERVED}

Hardness. The hardness of wheat varies greatly in different sections of the country. This is due to the definite effect of enviromment. Wheats grown in a region of abundant rainfall and under humid conditions, are usually softer and lighter colored and lower in protein content than wheats grown under dryer conditions.

Winter wheats grown in most of the states east of the Mississippi river are of the softer type and known as "red" winter wheats, while those grown in the belt of country bordering on the semi-arid and rumning through Nebraska, Kansas, and Oklahoma, are generally of the hard, dark red type and known as "hard" winter wheats.

The hard winter wheats are mostly of the Turkish Red variety. The characteristics however which mark it as a hard winter wheat, are due to environment, since this same variety if grown in Illinois for example, soon loses its hard qualities and grades instead as a "red" winter wheat.

The same is also true of spring wheats, the famous "No. 
1 Hard Spring" coming from the somewhat dry cimate of the Dakotas, Minnesota, and the Northwest.

Northern wheats are generaily somewhat hurder than southern, though this quality seems to depend on soil and climatic conditions more than on latitude.

Texture. Texture and hardness are closely correlated. The textrie is examined by making cous sertions of the grain and is described as horny, when it is foumd to he dark and vitreous in appearaner. with no starch showing. Opposed to these are the grains which are white aud starchy throughout. Whis is the dunderistic appenrance of the soft white wheats of the Pacific coast and Australlia, while the horny textme is charateristic of the manaroni, all hard winter and spling wheats. Wheats of a horny texture are generally higher in protein content, and produce a stronger flour.

Height. The weight per measmed hushel has always been :coneded as of the greatest importance in judging the quality of wheat. In a general way, it is true that a good wheat nerer has a low wight per bushel, while a poor wheat is never high in weight.

Light weight may be due to immaturity, to premature dry weather or hot winds, or the attacks of insects. The skin is wrinkled and not well filled ont with starch. The weight of good wheat may be reduced by exposure to inclement weather when part of the wrain is sprouted or is swelled and soaked by water until it never quite regains its normal size, or is overheated in the stack, called stack burning, or piled up in bins when too damp, causing heat and mould.

Soundness. A good No. I wheat should have no sprouted, decayed or injured grains from any canse, as exposure, stack burning, ol moths. A No. 2 wheat might have a few discolored grains, but none sproited. A No. 3 wheat if dry and in good combition otherwise, unight contain a few sprouted grains. However, the number of 
injured grains which may pass in a wrable, depends lamgely on how wood the wheat was before sulfering injury, the present rryuess, etce, of the sample. Grading is always based as near as possible on the actual milling quality of the grain.

Mustiness. 'This is caused usually by dampness, either while the grain is in stack or bin. Musty wheat is almost worthless for flomr, sine the gralin is permeated with a musty flaror. For this reason, eren a slight trace of must is always discriminated against, even though the wheat may still be used for low grate flomen. Musty grain is often worked into chop or some form of steck food.

colos: Wheat ranges in color from nearly a brick red, throwgh various shades of biown to almost white. In a general way, wheats from mild and himid climates are light colored, while those of colder and dry climates are dark. Some have a smooth, bright appearance, while in others the color is dull. Cxood wheat should not be beached or in any way discolored, but generally bright and in the hard wheats have a vitreons appearance. The occurrence of "yellow berries" in hard wheats, greatly depreciates its value as they give a yellow color to the flour.

"Stack burning" gives wheat a dark and somewhat burnt apprarance; exposure to weather, a bleached and dull appearance, while overheating in the bin, usually a whitish appearance and musty smell.

\section{WHEAT INSPECTICN RULES*}

No. 1 lied Winter Wheat shall be pure Red Wintel Wheat of both light and dark colors of the shorter berried varieties, soind, plump, and well cleaned.

No. 2 Red Winter Wheat shall be Red Winter Wheat of both light and dark colores, sound and reasonably clean.

No. 3 lied Winter Wheat shall include Red Winter Theat not (lean and plump ('nough for No. 2, but weighing not less than fifty-four pounds to the measured bushel.

*Rules adopted by the Board of Railroad and Wrehouse Commissioners lor the insperition of grain at Chicago. 
No. 4 Red Winter Wheat shall inchule Red Winter Wheat, damp, musty, or from any cause so bally damaged as to render it unfit for No. 3.

Red Winter Wheat containing a mixture not exceding five per cent of White Winter Wheat shall be ciassed as lbed Winter Wheat.

Red Winter Wheat containing more than five per cent ef White Winter. Wheat shall be sraded according to the quality thereof and classed as White Winter Wheat.

Hard Winter Wheat. The grades of Nos. 1, 2, 3 and 4 Fard Winter Whest shail correspond in all respects with the grades of Nos. 1, 2, 3 and 4 lied Winter Wheat, except that they shall be of the Turkish rariety.

In case of mixtme of Turkish lied Winter Wheat with lied Winter Wheat, it shall be graded according to the quality thereof, and classed as Harl Winter Wheat.

Spring Wheat.

No. 1 Northern Spring Wheat must be Northern grown Spring Wheat, somnd and reasmalsy clean and of goord milling quality and must contain not less thau 50 per cent of the hard varicties of Spring Wheat.

No. 2 Forthern Spring Wheat mist be Sorthern glown spring Wheat, not clean enough or somul enough for No. 1, and must contain not less than 50 pere cent of the hard varieties of Spring Wheat.

No. 1 Spring Wheat shall be somnd, plump, and well cleaned.

No. 2 spring Wheat shall be sommd, reasomahly clean, and of good nilling quality.

No. 3 spring Theat shall inchude all inferior, shrunken, or dirty spring Wheat, weighing not less than fifty-three pounds to the measured bushel.

No. 4 Spring Wheat shall include spring Wheat, damp), musty, sprouted, badly bleached, or for any canse which renders it unfit for No. 3.

White Spring Wheat. The orades of Nos. 1, 2, 3 and 1 
White Spring Wheat shall correspond with the grades of Nos. 1, 2, 3 and 1 Spring Wheat, except that they shall be of the White variety, or shall contain 5 per cent, or more, of such White Wheat.

Frosted Wheat shall in no case be graded ligher than So. 1, except that the grade of No. 3 may contain as much of said Frosted Wheat as it is customary to allow of Wheat damaged in any other way.

Mixed Wheat. The grades of Nos. 2 and 3 Hixed Wheat shall be equal in quality to the grades of Nos. 2 and 3 Red Winter Wheat, except that they shall inchude mixtures of Spring and Winter Wheat.

In examining a sample of wheat, it is well to take up each point, one at a time at first, as "hardness" or "texture" and examine the sample for this. Make a note of your observation in each case. After the sample has been carefully examined in this way, make out a brief report on each sample, sometling after the following plan:

\begin{tabular}{|c|c|c|c|}
\hline $\begin{array}{l}\text { No. } \\
\text { SAMPLE }\end{array}$ & GRADE & $\begin{array}{c}\text { WEIGHT } \\
\text { PER BUSHEL }\end{array}$ & REMARKS \\
\hline 1 & $\begin{array}{l}2 \text { Hard } \\
\text { Winter }\end{array}$ & $58 \mathrm{lbs}$ & $\begin{array}{l}\text { Horny texture, few "yellow ber- } \\
\text { ries." }\end{array}$ \\
\hline 2 & $\begin{array}{l}3 \text { Red } \\
\text { Winter }\end{array}$ & $56 \mathrm{lbs}$ & $\begin{array}{l}\text { Many bleached kernels; lacks } \\
\text { plumpness, slightly musty. }\end{array}$ \\
\hline
\end{tabular}

TESTING WHEAT FOR PURITY

Standard for Purity 99 per cent.

Test of Purity: Take about a half pint sample and spread on table, carefully separate all impurities, as weed seeds, straws, etc. Then find by weight the amount of pure seed and foreign matter, and calculate per cent of purity.

Examine the foreign matter carefully and identify the varieties of weed seeds found.

TESTING WHEAT FOR VIABILITY

Standard for Germination 90-95 per cent.

Sampling: If taking the sample from a bin, do not take it from one spot but thoroughly mix several shovelfuls, 
then take out a small sample and select at random from this 100 grains. Place in moist chamber as described on page $6 \mathrm{I}$ and moisten daily. Keep as near as possible at a temperature ranging from $80^{\circ}$ to $90^{\circ} \mathrm{F}$. Germination should begin in three days, and be complete in about six.

When the radicle has reached a length of $\frac{1}{4}$ inch or more, the germination is sufficient. Remove the sprouted grains daily until germination has ceased, then by counting the number of grains left and subtracting this number from 100, you have the per cent of germination.

\section{CORN}

\section{CLASSIFICATION OF SPECIES.}

The different groups of corn are classified as follows:

Order ......................Gramineae

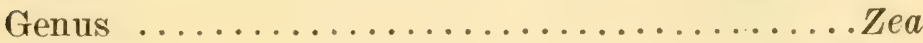

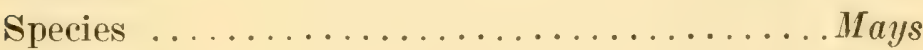

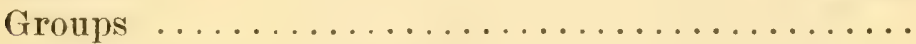

Zea tunicate, the pod corn.

Each liernel is enclosed in a pod or husk, and the ear enclosed in husks. Rare. Very leafy, hence called "Cow corn."

$Z$. evorta, the pop corn.

Characterized by the excessive proportion of corneous endosperm and the small size of the kernels and ear. Kernel is pointed oval in form. The best popping varieties are corneous throughout. Popping is caused by the explosion of contained moisture on heating.

Z. indurata, the flint corns.

Characterized by starchy endosperm enclosed in corneous endosperm. They are oval in form. In some varieties the corneous portion is very thin at top and a slight indentation appears.

$Z$. indentata, the dent corns.

Characterized by corneous endosperm at the sides 
of the kernel, the starchy endosperm extending to the summit. By drying and shrinkage of the starchy matter the summit of the kernel is drawn in or together, and indented in various forms.

The kernel is long and wedge shaped. Most exteusively grown, and has largest number of varieties.

Z. amylacea, the soft corns.

Characterized by the absence of corneous endosperm. All starchy. No indentation. Shrinks uniformly. Shaped like flint but soft.

Z. saccharata, the sweet corns.

Characterized by the trauslucent, horny appearance of the kernel, and the more or less wrinkled, or shriveled condition.

Shrinking due to change of starch to glucose. Trelge shaped kernel.

\section{Varieties of Corn.}

The so-(a)lled valieties of corn are, like those of wheat, rery numerous.

Varieties of the dent type are most commonly grown in this country.

Flint corm ripens earlier and is adapted to the more northern latitudes.

bent corn grows larger and yields heavier.

While there are numerous so-called valieties, there are only a few distinct and recognized breeds of uniform characteristics.

Owing to the ease with which varieties are produced each locality generally has varieties peculiarly adapted to it.

\section{LABOR.ATORY S'TUDY OF" SPECIES AND OF CHARAC'TERS.}

\section{EXAMINATION OF SPECIES}

Samples on the stalk of the various types of corn are provided. 
For each of the six principal groups of corn, carry out the following outline:

Describe a typical ear, as to color, shape, inclentation, and depth of grain, length, etc.

Make drawings of both longitudinal and cross-sections of grains, showing ly appropliate shading where the germ, the starchy portion, and horuy portions of the grain are located.

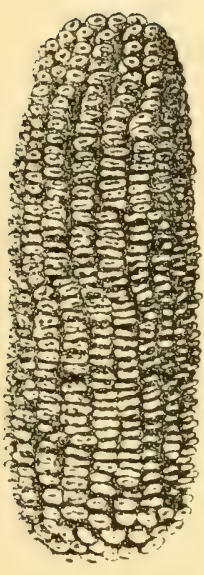

Fig. 1

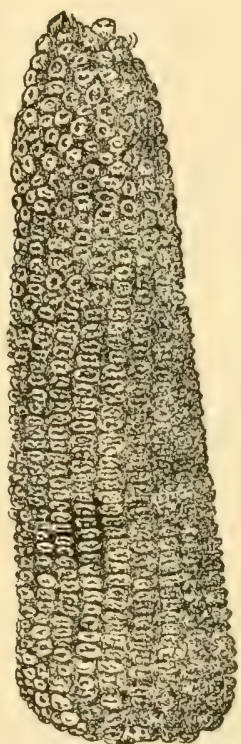

Fig. 2

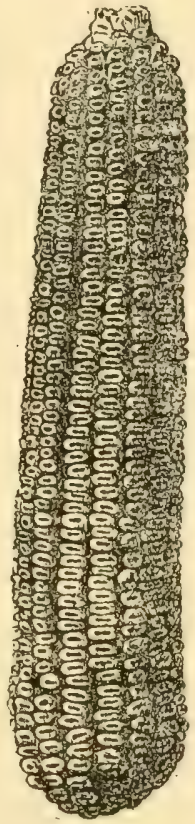

Fig. 3

Plate 7

These three ears of corn possess among them most of the characters covered by the score card. See "Terms for describing characters."

\section{TERMS FOR DESCRIBINंG CHARACTERS}

Shape of Ear.-

Cylindrical (Plate T, Fig. 1).

Tapering (Pl. 7, Fig. 3).

Very tapering (Pl. T, Fig. 2). 
Length of Ear.-

Long (over 10 inches) (Pl. 7, Fig. 3).

Medium (8 to 10 inches) (Pl. 7, Fig. 2).

Short (under 8 inches) (Pl. 7, Fig. 1).

Circumference of Ear.-

Large (over 8 inches)

Medium ( 6 to 8 inches).

Small (under 6 inches)

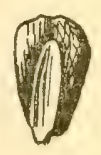

1

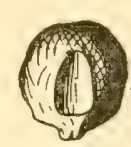

2

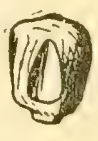

3

Plate 8

Typical shapes of kernels.

Color of Kernel.-

Light yellow

Dark yellow

White

Indentation of Kernel.-

Smooth (Pl. 7, Fig. 3).

Dimpled (Pl. 7, Fig. 2).

Deeply dented (PI. 7, Fig. 1).

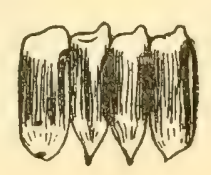

1

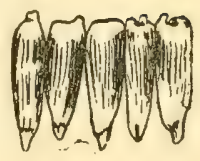

2

Plate 9

Side view of typical kernals

Shape of Kernel.-

Wedge (Pl. 8, Fig. 1).

Round (Pl. 8, Fig. 2).

Square (Pl. 8, Fig. 3).

Pointed (Pl. 9, Fig. 2).

Parallel sided (Pl. 9, Fig. 1). 
Length of Kernel.-

Long (Pl. 10, Fig. 2).

Medium.

Short (Pl. 10, Fig. 1).
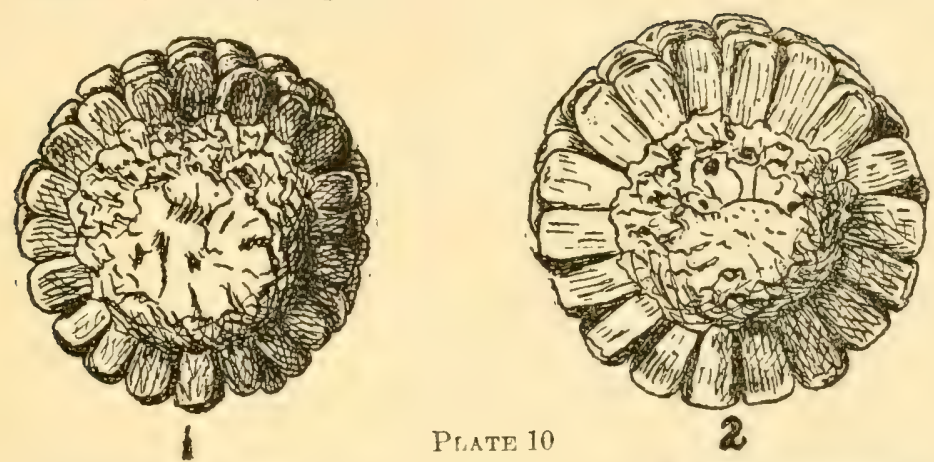

Cross section of ears. 1, short, round kernels. 2, deep, wedge-shaned kernels.

Number of rows of kernels.-

Many ( 20 or more).

Medium (14 to 20$)$.

Few (under 14).

Space between rows.-

At cap of kernel.

Wide (Pl. 10, Fig. 1).

Close (Pl. 10, Fig. 2).

At cob.

Close (Pl. 11, Fig. 1).

Wide (Pl. 11, Fig. 2).
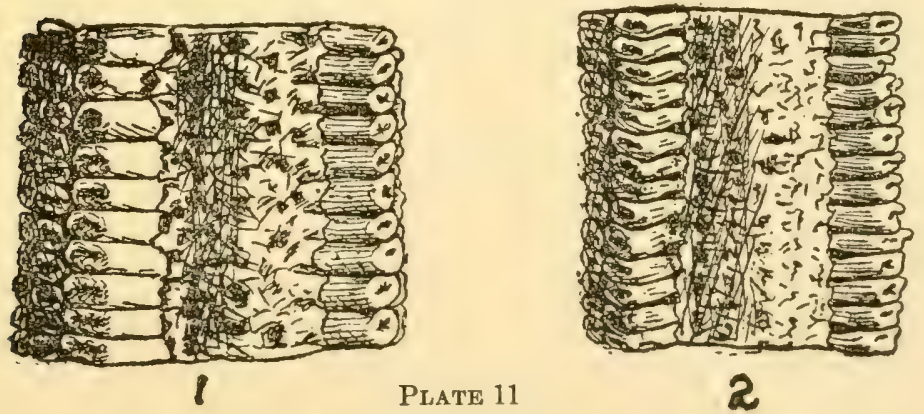

Plate 11

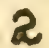

Longitudinal sections of ears. 1, kernels close together at cob. 2 , kernels fur apart at cob. 
Arrangement of rows.

Distinct.

Paired.

Tips.

Corered (Pl. 7, Fig. 1).

Exposed (Pl. T, Fig. 3).

sirell of Butt.

Deeply rounded (Pl. 12, Fig. 2).

Noderately rounded.

Flat (Pl. 12, Fig. 1). Size of Butt.

Enlarged (Pl. T, Fig. 3).

Uniform (Pl. T, Fig. 1).

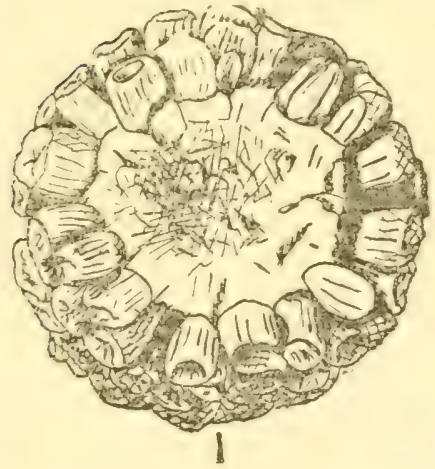

Plate 12

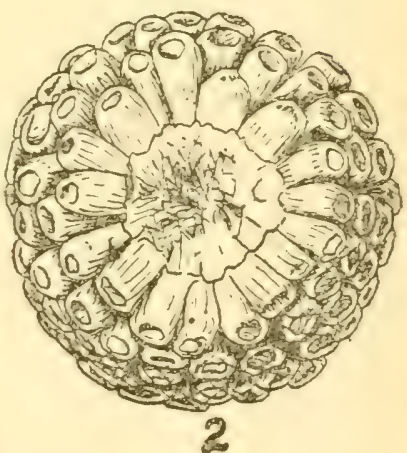

Butts of ears. 1, poorly filled butt, shank too large. 2, well filled butt, Size of Shank. shank small.

Small (Pl. 12, Fig. 2).

Medium.

Large (Pl. 12, Fig. 1).

Size of Cob.

Small.

Medium.

Large.

Color of Cob.

Red.

White.

For this exercise select ear's or kernels that possess each of the characters mentioned under each head. 
OUTLINE FOR DESCRIBING CORN

Variety name .............. Number of sample...

EAR

Shape

Length

Circumference

KERNEL

Color

Indentation

Shape

Length

\section{ROWS}

Number

Space
At cob

Arrangement

TIP

BUTT

Swell

Size

SHANK

Size

$\mathrm{COB}$

Size

Color

At cap

Student's name

Date

OUTLINE FOR COMPARING VARIETY TYPES

Take a representative ear of each of two varieties of corn and fill in spaces with an appropriate description of each.

Shape-Cylindrical, Slightly tapering, Tapering, Very tapering.

1. Boone County White

2. Reid's Yellow Dent

Length.-Give length from butt to tip in inches.

1. Boone County White

2. Reid's Yellow Dent 
Circumference-Give circumference of ear at one-third the distance from the butt.

1. Boone County White

2. Reid's Yellow Dent

Color of Kernel.-Light yellow, Dark yellow, White.

1. Boone County White

2. Reid's Yellow Dent

Indentation of Kernel.-Smooth, Dimpled, Dented, Deeply dented.

1. Boone County White

2. Reid's Yellow Dent

Shape of Kernel.-Wedge, Round, Square, Rectangular.

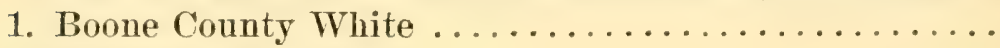

2. Reid's Yellow Dent

Length of Kernel.-Measure from crown to tip of true kernel.

1. Boone County White

2. Reid's Yellow Dent

Number of rows of Kernels. -

1. Boone County White

2. Reid's Yellow Dent

Space between rows.-Measure in $32 \mathrm{~d}$ parts of an inch.

1. Boone County White

2. Reid's Yellow Dent

Arrangement of rows.-Distinct, Paired.

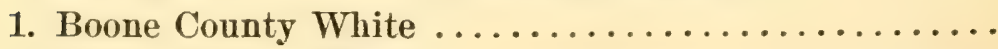

2. Reid's Yellow Dent

Butts.-Deeply rounded, Moderately rounded, Flat, Enlarged, Uniform.

1. Boone County White

2. Reid's Yellow Dent

Shank.-Small, Medium, Large.

1. Boone County White

2. Reid's Yellow Dent

Size of Cob.-Small, Medium, Large.

1. Boone County White

2. Reid's Yellow Dent 
Color of Cob.-Red, White.

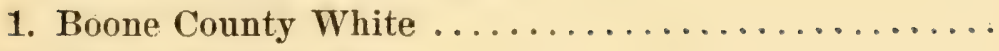

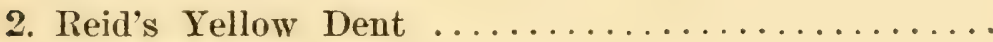

\section{JUDGING CORN.}

Results obtained by numerous seed corn growers have demonstrated beyond doubt that the productiveness of corn can be greatly increased br the selection of ears having certain desirable qualities for seed. All of the well known varieties of corn have been developed by years of careful selection of seed ears. The principle involved is that an ear of corn when planted reproduces more or less closely its own characteristics in the resulting ears. By selecting for seed, ears of uniform size, deep liernels and other desirable characters, we largely aroid the production of nubbins, shallow kernels and other objectionable points and thus increase the yield.

\section{POINTS TO BE OBSERVED}

Uniformity of Exhibit.-The points that go to produce uniformity of exhibit are size, shape and color of ear, appearance of tips and butts, and indentation of kernel. The ears should closely resemble each other in these characters. In other words each ear should look as much as possible like every other ear. In considering this point the judge is not called upon to decide as to the desirability of the characters possessed by the different ears, but solely as to their similarity.

The judge places the ten ears side by side on a table or bench with the butts towards him. He then by removing one ear and replacing it by another, sorts over the exhibit until he has the similar ears lying side by side. If there are six similar ears of one type and four of another, he credits the exhibit with six similar ears, even should these not be so desirable as those of the other type.

Shape of Ears.-Leaving the exhibit arranged as before, count the number of ears that are cylindrical or nearly so. 
Credit the exhibit with such ears only. A cylindrical ear is desirable because it permits the growth of kernels of uniform shape, and such ears generally have a larger proportion of corin to col). A tapering ear must have kernels becoming smaller from butt to tip or else must drop out one row or more entirely between the butt and tip. In either case badly shaped and small kernels are produced.

color of Cobs. - The color of the cob is, to some extent, a guide to the purity of breeding of the exhibit. The presence of a white cob in an exhibit of otherwise red cobs is an indication that at some time there has been a cross with a white cob variety. This may have occurred many years before, and may not be a present detriment to the corn, but, on the other hand, it may have been detrimental and for that reason is discountenanced. The same is true of the presence of a red cob in an exhibit of otherwise white ones. Some varieties of corn having white kernels have red cobs, but in such a case there should be no white cobs in the exhibit.

Color of tiernels. $-\Lambda$ yellow kernel on a white ear or a white kernel on a yellow ear shows that the corn has been fertilized by pollen from corn of another color. In other worls it shows that the rariety is not strictly pure. The cross fertilization may have occurred in the year in which the ear was raised or it may be of earlier date; there is no way of distinguishing, but the fact is equally objectionable in either case.

Each kernel on the ear results from the fertilization of its ovary by pollen from the same plant or some other. The pollen is borne on the tassel. If any ovary is fertilized by pollen from corn of a different color, the resulting kernel will be of a different color from the rest of the ear.

A mixed kernel on a yellow ear may be readily seen as the crown of the kernel is white. On a white ear, the crown of a mixed kernel hardly shows the yellow color, but it may be seen on the part of the kernel beneath the 
crown. They are therefore harder to discover, and the judge must look very carefully.

Warket Condition.-The market condition of corn depends most largely upon its ripeness. Other conditions such as freedom from smut or worms, and brightness of color also enter into considerution to some extent. The degree of maturity is commonly determined by the firmness $01^{2}$ looseuess of the kernels on the col), and by the stiffness of the cob. Take in turn each ear in the hand and attempt to trist it. If the cob twists leatily it is not well matured. If the cob is stiff see if the kernels are loose on! the coln. Looseness of the kernels indicates inmataity.

Tips of Ears.-The tips of the colos are very likely to protrude beyond the kernels. The extent to which this occurs will vary with the season, and with the strain of coln. The reason that the tips are consinged in soleting

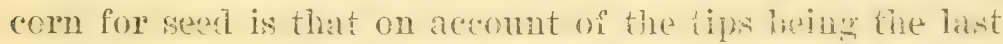
part of the ear to throw out silks, there is a possibility that the strain may acopuire the hant of deredoning the tip silks too late to be fertilized shonht ears withont tip lerenels be continually selected for seed.

On the other hand it is argued that in the main, tips that are well filled out are found on ear's of less than average length, and that their selection for seed must result in shortening the ear. However, where a certain length of ear is a requisite for seed coru, it is doubtful whether this argument will hold.

'Butts of Ears.-As the ideal ear is cylindrical in shape, the butt should be uniform in diameter with the rest of the ear. It should be well rounded and symmetrical, the rows extending in a uniform way well orer and around the shank. The butt should not be expanded or enlarged, since this usually goes with an abnormally large shank which makes husking more difficult. The expanded butt is generally due to an enlargement of the cob, and is not well filled over while the liernels are short and irregular, 
thus reducing the percentage of corn. On the other hand the butt may be contracted or filled over too far. In either case the shank is apt to be too small, increasing the tendency of the ears to drop off before husking time.

Uniformity of Kernels. - The kernel shape varies with varieties, but whatever the shape, if the corn is a well selected raricty, the kernels should be similar in shape. In judging for uniformity, first remove two kernels from near the middle of each ear and lay them near one end of the ear with the tips of the kernels toward you. In this way remove two kernels from each ear, placing the ears and pairs of kernels side by side, when the comparative size, shape, etc., of the different pairs of kernels may be noted.

The indentation of the kernels is best compared on the ears. Count the number of ears having kernels which are in a general way uniform and score the exhibit accordingly.

Shape of Kcructs.- In general the shape of the kernel should be that of a wedge, as this shape permits the greatest amount of corn on the cob. The kernels should be of such shape that they fit snugly from tip to crown. If the kernels are too wedge shaped there is a loss of space at the tips of kernels, while if they are too rectangular there will be wide spaces between the rows at the crown. The kernels should not be too thin at the tip but about the same thickness as at the crown. Pointed, thin kernels are often low in vitality and of less feeding value than kelnels having plump, well developed tips. In judging shape of kernel, remove a few kernels from near the middle of the ear, and examine the kernels on the ear, noting the spacing between the tips and crowns, and how closely they fit.

The length and indentation of the kernels should also be noted. A good indentation is of importance, since a deep indentation secms to go with a deep grain. In pick- 
ing seed ears, only well indented ears should be selected, as this is the only practical way of keeping up a good depth of kernel.

Space between Kernels.-The space between kernels is closely correlated with shape of kernels. Well shaped kernels should have no lost space between rows either at tips or crowus. In examining spaces between rows, remove several kernels near the middle of the ear, and examine the space between tips of kernels, both when looking at the side of the row and the ends of the rows. Then examine the spaces between rows at the top of kelnels; this should as a general thing be less than $1 / 32 d$ inch, though this rule cannot be rigidly observed. Too much space not only results in poorly shaped and irregular kernels, but in a decreased percentage of corn.

Proportion of Corn on Ear.-The reason for determining this point is primarily to discourage the production of a large cob, while it also encourages a deep kernel. The effect of this point in connection with the following one is to prevent the growth of an ear unduly large in circumference in proportion to its length.

The proportion of corn on the ear is determined by weighing five representative ears of the exhibit, shelling the grain, and reweighing the cobs. The difference between these weights divided by the weight of the ears gives the per cent of corn on the ear.

Weight of Corn on Ear.-While a very large ear of corn is not, under all conditions desirable for seed, it is to be desired that an ear of a given length should possess a maximum quantity of grain. By requiring an ear of given length to shell out a certain weight of grain, a deep kernel is placed at a premium, as is also a heavy kernel. The danger of producing a deep but light weight kernel is thus avoided.

It is well understood that a deep kernel requires a long growing period for its development. Should the growing 
season not be farorable or should the attempt be made to raise a type of corn having a kernel too deep for the climate in which it is planted, the result would be a comparatively deep but light weight kelnel. To discourage this the weight requirement is made.

SCORE CARD FOR CORN

Variety name .............. Number of exhibit.....

\begin{tabular}{|c|c|c|c|}
\hline & VALUE & $\begin{array}{l}\text { STUDENT'S } \\
\text { SCORE }\end{array}$ & $\begin{array}{c}\text { CORRECTED } \\
\text { SCORE }\end{array}$ \\
\hline Uniformity of exhibit........ & 10 & & \\
\hline 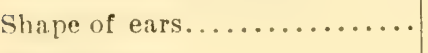 & 10 & & \\
\hline Color of cob $\ldots \ldots \ldots \ldots \ldots$ & 5 & & \\
\hline Color of kernels.............. & 5 & & \\
\hline Market condition ............ & 10 & & \\
\hline Tips of ears $\ldots . . . \ldots \ldots \ldots \ldots$ & 5 & & \\
\hline Butts of ears ................ & 5 & & \\
\hline Uniformity of kernels......... & 10 & & \\
\hline Shape of kernels............. & 10 & & \\
\hline Space between kernels ........ & 5 & & \\
\hline Proportion of corn on ear..... & 10 & & 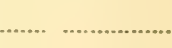 \\
\hline Weight of rrain .............. & 15 & & \\
\hline
\end{tabular}

Student's Name ..............Date..........

RULES FOR JUDGING EXHIBITS OF CORN

Uniformity of Exhibit.-The ears in an exhibit should be similar in size, shape, color and indentation. For each ear deficient in these respects, cut the exhibit one point.

Shape of Ears.-The ears should be cylindrical or nearly so. Cut the exhibit one point for each ear deviating from this requirement.

Color of Cob.-The cobs should be uniformly red or uniformly white. For each white cob in an exhibit in which the red predominate, cut the exhibit one-half point. Do the same for each red cob in an exhibit of white cobs.

Color of Kernels.--For each white crowned kernel in a yellow or red variety, cut the exhibit one-tenth point. For each yellow kernel in a white variety, give the same cut. 
Marlict Condition.-The corn should be well matured. firm and sound. For each ear deficient in these respects, cut the exhibit one point.

Tips of Ears.-The tips of the ears should be covereal with regular, uniform kelnels. Add together the lengths of protruding cols on all ears of the exhibit, and cut at the rate of one-half point for each inch.

Butts of Eurs.-The Iows of kemels should be even and swell out evenly beyoud the end of the cob. Cut the exhibit one-half point for each poorly filled butt, and onefourth point for each flat butt.

Uniformity of Kemcls.-Whe kermels should possess similar characters. Cut the exhibit one-half point for each deficient ear.

Shape of Kernels.-The kernels should have a wedge shape on the broad side, and on the narrow side the edges should be parallel. Cut one point each for each objectionable ear.

Space Beturen Kerncls.--The rows of kernels should not be more than one-thirty-second of an inch apart at any part of the row. If more than one-sixteenth of an inch apart, cut one-half point, if less than that but more than one-thirty-second, cut one-fourth point for each ear.

Proportion of Corn on Ear.-The proportion of corn on the ear should not be less than 85 per cent. For every per cent below eighty-five, cut the exhibit one point.

Weight of Grain.-The weight of grain on an average ear should come up to the following requirements:

Length of Ear 12 inches and over, weight of grain 17 ounces.

Length of Ear 11 to 12 inches, weight of grain 15 ounces. Length of Ear 10 to 11 inches, weight of grain 14 ounces. Length of Ear 9 to 10 inches, weight of grain 13 ounces. Length of Ear 8 to 9 inches, weight of grain 11.5 ounces. Length of Ear 7 to 8 inches, weight of grain 9.5 ounces. 
Length of Ear 6 to 7 inches, weight of grain 8 ounces.

For each ounce below the number required by an ear of given length, cut the exhibit one point.

\section{TESTING CORN FOR VIABILITY.}

Standard for Germination 90-95 per cent.

Sampling.-The importance of making germination tests of corn cannot be emphasized too strongly since seed corn will often have a fair outward appearance and yet germinate poorly.

When the germinating power of corn is very low, and reliable seed is hard to pick out, it is often desirable to make germination tests of each ear separately.

To do this, first number the ears by slipping a piece of cardboard containing the number between two rows. Then remove one grain from the butt, middle and tip of each ear. Then taking your germinator, as described on page $6 \mathrm{r}$, mark off the blotting paper in the bottom into inch squares, numbering each. Now put the grains from each ear in their respective square, and allow to germinate.

In this way several hundred ears may be tested at once.

For testing a large lot of corn in the ear, select 100 ears at random and take one grain from each of these about two inches from the butt. More corn seems to germinate peorly near the butt than at any other point. Place seed in germinator. Germination should begin in about two days and be complete in six.

For best results keep temperature as near $80^{\circ}$ to $90^{\circ} \mathrm{F}$. as possible, and never let fall below $60^{\circ} \mathrm{F}$.

\section{GRADING CORN.}

The grades of corn are usually designated "White Corn", "Yellow Corn", or in case of a mixture of the two (amounting to more than 25 per cent), it is simply called "Corn." 
Usually three grades of White and Yellow corn are made, and four grades of the Mixed corn. In examining and grading corn, the student should take into consideration the following points:

\section{POINTS TO BE OBSERVED}

Color.-No. 1 Corn should be true to color, but in grades 2 and 3 , considerable mixture is allowed, varying from 10 per cent to 25 per cent.

Soundress. Good corn should not only be thoroughly cleaned up, but be reasonably free from decayed or cracked kernels. Cracked kernels often indicate that the corn was damp when shelled. Any considerable per cent of chaffy or shrunken kernels injures both the feeding and milling value of the corn.

Moisture. Corn in a wet or heating condition cannot be graded.

Go over each sample carefully and make out a short report on each, giving first the commercial grade, then note the amount of mixture, if mixed, also the kind and nature of any impurities or injury the grain may have suffered from exposure, sprouting, or heating in crib or bin. The following form of report is suggested:

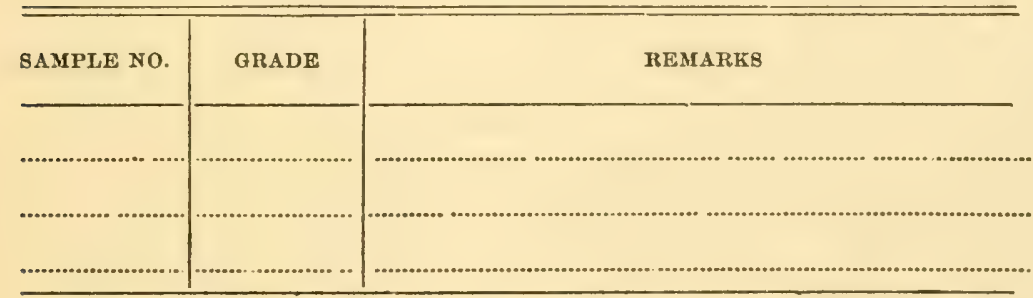

For this work 20 to 25 samples of corn are provided. These should include samples of pure yellow and white corn of the various grades, in various stages of cleanliness, dampness, etc. Also samples of mixed corn, starting in with pure white and yellow and mixing them in various proportions. 
No. 1 Yellow Corn shall be yellow, sound, dry, plump, and well cleaned.

No. 2 Yellow Corn shall be three-fourths yellow, dry, reasonably clean, but not plump enough for No. 1.

No. 3 Yellow Corn shall be three-fourths yellow, reasonably dry, and leasonably clean, but not sufficiently sound for No, 2.

No. 1 White Corn shall be sound, dry, plump, and well cleaned.

No. 2 White Corn shall be seven-eighths white, dry, reasonably clean, but not plump enough for No. 1 .

No. 3 White Corn shall be seven-eighths white, reasonably dry and reasonably clean, but not sufficiently sound for No. 2.

No. 1 Cor'u shall be mixed corn of ehoice quality, sound, dry and well cleaned.

No. 2 Corn shall be mixed corn, dry and reasonably clean, but not good enough for No. 1 .

No. 3 Com shall be mixed corn, reasonably dry and reasonably clean, but not sufficiently sound for No. 2.

No. 4 Corn-Corn that is badly damaged, damp or very dirty shall be graded no higher than No. 4 .

Corn that is wet or in heating condition shall not be graded.

\section{OATS}

\section{CLASSIFICATION OF SPECIES.}

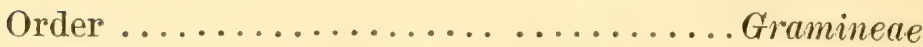

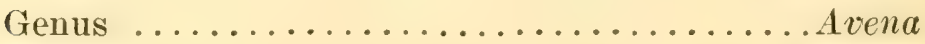

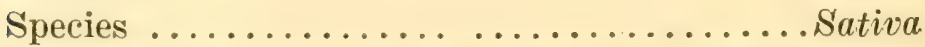

The cultivated varieties are sometimes classified according to the form of the panicle, and considered by some botanists as distinct species. The "common oat"-Avena sativa-comprising those varieties having spreading pan-

*Rules adopted by the Board of Railroad and Warehouse Commissioners for the inspection of grain at Chicago. 
icles, and the "Tartarian oat"-Avena oricntalis-comprising varieties with close, erect panicles commonly called "side oats" while the other is called "branch oats."

There is also a type, Avena muda, from which the hull is removed in threshing. Varieties of this are found in both of the above groups.

The hulled varieties are also divided, according to the color of the hull, into white, gray, red, and black oats.

The oat differs from the other cereals in having its heads in the form of panicles instead of spikes and the grain is not attached directly to the main stem of the plant.

In form of grain and height of straw varieties differ considerably.

A good oat grain should be fairly plump, have a thin hull and weigh 32 to 35 pounds per measured bushel.

The stalk should be of medium height, having a long panicle and stand erect.

As in the case of most other cereals the varieties of oats are very numerous and adapted to different conditions.

In regard to yield and quality there seems to be on an average no particular difference between varieties of different color, or varieties with open or closed panicles. The differences seem to be due solely to induced variety characteristics.

The shape of the grain varies considerably in different. varieties, some being very long and having a large proportion of hull.

In the southern regions the proportion of hull to kernel tends to increase.

Remove hulls of several varieties and get proportion by weighing. (Hulls are more easily removed if soaked in a dilute solution of potassium hydrate or 33 per cent alcohol for a few minutes.) 
(It will be noted that the kernel is enclosed in a hull. The feeding value is decreased by a large proportion of this hull.)

\section{LABORATORY STUDY OF CHARACTERS.}

Examine in head samples of common varieties of side and panicled oats.

Draw a branch and two or three spikelets.

Dissect out carefully a spikelet and draw its parts in their relative position.

Now examine each head carefully and note down its characteristies in the "Ontline for Describing Oats", using the list of descriptive terms as a guide. 

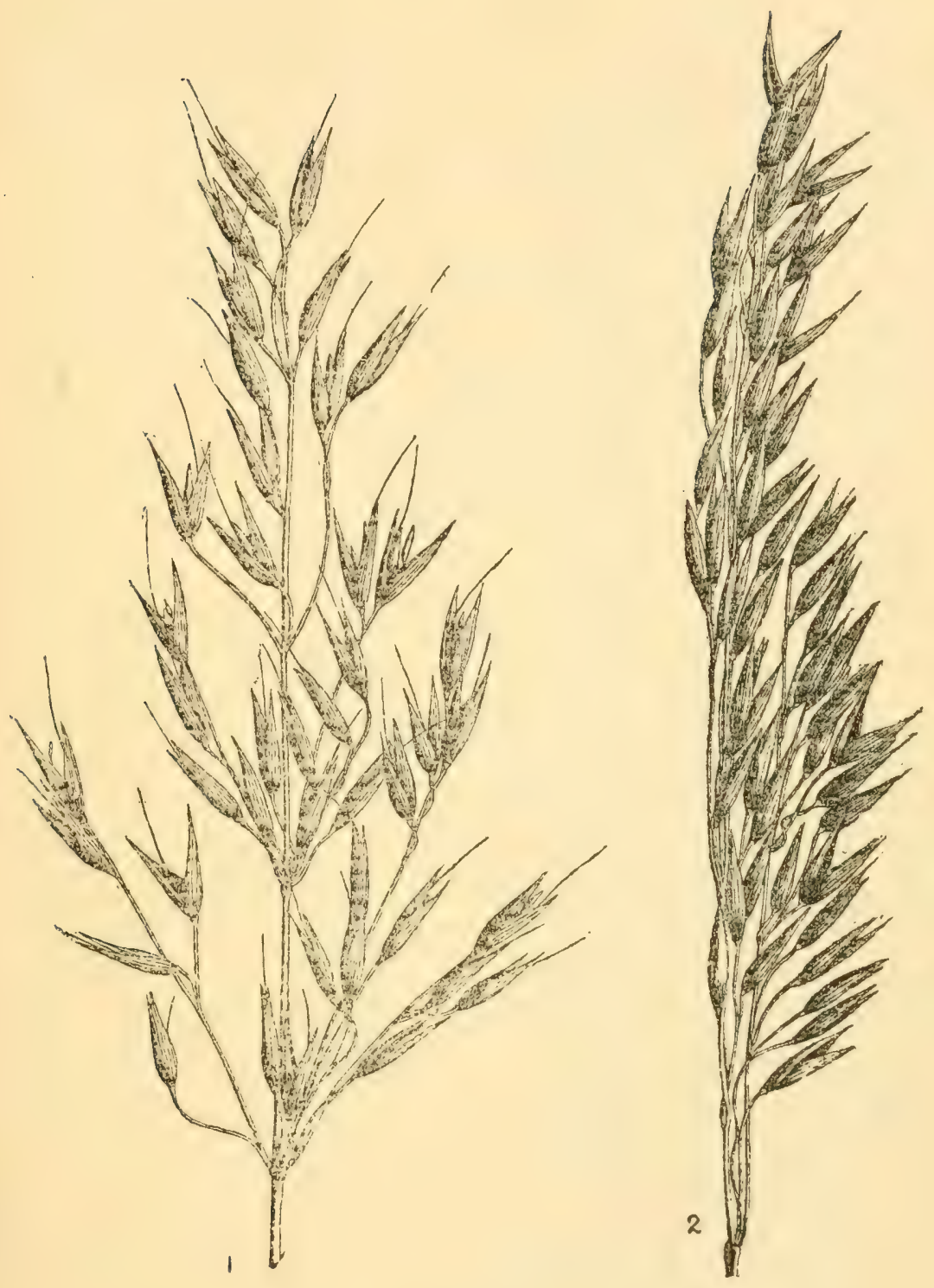

Plate 13

Types of oat heads; No. 1, panicled oats; No. 2, side oats. 
TERMS FOR DESCRIBING CHARACTERS

Variety name ............... Number of sample...

PANICLE

Shape

fOpen (Pl. 13, Fig. 1)

Spreading

1. Compressed

$\left\{\begin{array}{l}\text { Side panicle } \\ \text { (Pl. 13, Fig. 2) }\end{array}\left\{\begin{array}{l}\text { Loose } \\ \text { Compressed }\end{array}\right.\right.$

2. Length (inches)

Color

Whitish

Yellowish

Y Yellow brown

$\{$ Brown

Reddish

Black

Gray

SPIKELET

1. $\left\{\begin{array}{l}\text { Spreading } \\ \text { Narrow }\end{array}\right.$

2. Number grains 1, 2, 3.

Outer Glume

TTip awn pointed

1. $\{$ Tip acute

Tip blunt

2. Medium

(Narrow

GRAIN

Shape

1. Medium

(Short (Pl. 14, Fig. 2)

2. Medium

lPlump (Pl. 14, Fig. 2)

3. Pointed at base

Blunt at base 
4. Wt. 100 grains

Tip

(Long (Pl. 14, Fig. 1))

1. Medium

(Refers to extension of hull beyond [Short (Pl. 14, Fig. 2)\} the naked grain.)

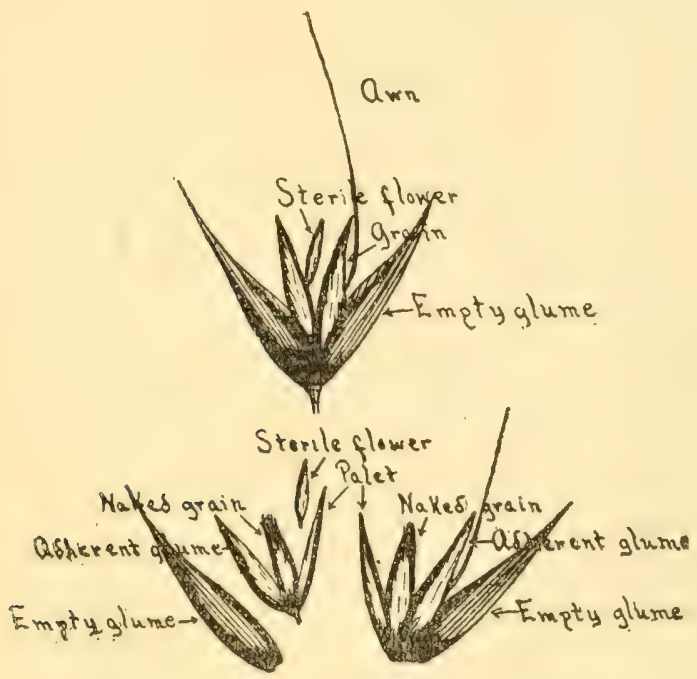

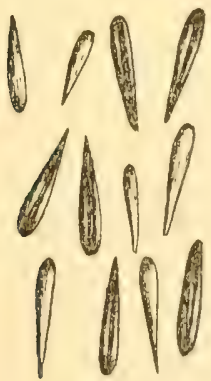

Fig. 1

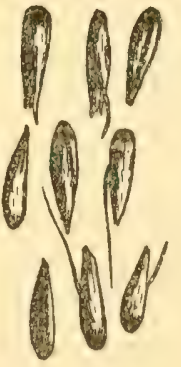

Fig. 2

Plate 14

The upper figures show an entire oat spikelet, both in its natural form and when torn apart, with all parts named. The lower figures show two types of oat kernels.

2. $\left\{\begin{array}{l}\text { Pointed (Pl. 14, Fig. 1) } \\ \text { Blunt (Pl. 14, Fig. 2) }\end{array}\right.$ 


\section{Hull}

1. $\left\{\begin{array}{l}\text { Thick } \\ \text { Medium } \\ \text { Thin }\end{array}\right.$

2. Per cent

Color

$\left\{\begin{array}{l}\text { Whitish } \\ \text { Yellowish } \\ \text { Brownish } \\ \text { Reddish } \\ \text { Black }\end{array}\right.$

Dorsal Awns

1. $\left\{\begin{array}{l}\text { Long } \\ \text { Medium } \\ \text { Short } \\ \text { None }\end{array}\right.$

2. $\left\{\begin{array}{l}\text { Slender } \\ \text { Medium }\end{array}\right.$

(Stout

3. $\left\{\begin{array}{l}\text { Deciduous } \\ \text { Persistent }\end{array}\right.$

Color

IWhitish

1. Brownish

Yellowish

Black

2. $\left\{\begin{array}{l}\text { Brown or black at base } \\ \text { and lighter at tip }\end{array}\right.$ 
Variety Name .............. Number of Sample....

PANICLE

Shape

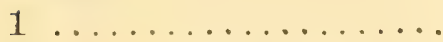

2

Color

1

SPIKELET

1

2

Outer Glume

1

2

GRAIN

Shape

1

2

3
Tip

1

2

Hull

1

2

Color

1

Dor'sal Awn

1

2

3

Color

1

2

Student's Name

Date

\section{EXAMINING AND GRADING OATS.}

For this work about 20 samples of oats are provided including one sample of each commercial grade.

$$
\text { POINTS TO BE OBSERVED }
$$

Mustiness. Oats should be free from must as it injures the palatability and feeding value of the grain; also giving horses a cough.

Purity. Oats should be fairly clean, but more foreign matter is allowed in oats than in corresponding grades of other grain.

An occasional grain of corn or wheat is not so objectionable in a grain used largely for feeding purposes as in a grain for milling.

Weed stems and seeds are not only worthless but mav give a bad taste to the grain. 
Plumpness. Other things being equal, a plump berry is always prefered, since it usually has a less proportion of hull, and consequently higher feeding value.

Somndmess. Decayed and weather beaten grain not only suffers in appearance, but the feeding quality is injured, since only a small amount is sufficient to injure that sweet, palatable flavor, which bright, clean oats should have.

Weight. The weight per bushel is a good indication of the feeding value of an oat since lighter oats have a larger proportion of hull to berre than heavy oats.

Good oats should weigh at least thirty-two pounds per bushel.

A No. 3 onts may weigh as low as twenty-two pounds if it is bright and clean.

\section{OAT INSPECTION RULES*}

No. 1 White Oats shall be white, sound, clean, and reasonably free from other grain, weight 32 pounds.

No. 2 White Oats shall be seren-eighths white, sweet, reasonably clean, and reasonably free from other grain, weight 28 pounds or above.

No. 3 White Oats shall be seren-eighths white, but not sufficiently sound and clean for No. 2, weight 22 pounds or better.

No. 4 White Oats shall be seven-eighths white, damp, badly damaged, mustr, or for any other cause unfit for No. 3.

No. 1 White Clipped Oats shall be white, sound, clean, reasonably free from other grain, and shall weigh not less than thirty-six pounds to the measured bushel.

No. 2 White Clipped Oats shall be seven-eighths white, sweet, reasonably clean, reasonably free from other grain, and shall weigh not less than thirty-four pounds to the measured bushel.

*Rules adopted by the Board of Railroad and Warehouse Commissioners for the inspection of grain at Chicago. 
No. 3 White Clipped Oats shall be seven-eighths white, not sufficiently sound or clean for No. 2, and shall weigh not less than twenty-eight pounds to the measured bushel.

No. 1 Oats shall be mixed oats, sound, clean, and reasonably free from other grain.

No. 2 Oats shall be sweet, reasonably clean, and reasonably free from other grain.

No. 3 Oats shall be mixed oats, not sufficiently sound and clean for No. 2.

No. 4 Oats shall be all mixed oats that are damp, badly damaged, musty, or for any other cause unfit for No. 3.

In examining and grading the samples of oats, take up each point separately, as in wheat, making notes of your observations, and report on each, after the following manner :

\begin{tabular}{c|c|c}
\hline No. SAMPLE & GRADE & REMARKS \\
\hline 1 & No, 2 Wheat & $\begin{array}{c}\text { Weight } 30 \text { lbs. per bushel, grains plump; slightly } \\
\text { mixture of corn; sweet and bright. }\end{array}$ \\
\hline
\end{tabular}

TESTING OATS FOR PURITY

Standard for Purity 99 per cent.

Test of Purity: Thoroughly mix the oats to be tested and take out about a half pint sample. Spread this on a table and carefully separate out the impurities. Then find by weight the amount of pure seed, as well as the foreign matter and from this calculate the per cent of purity.

An oat sample may sometimes contain as much as 5 per cent foreign matter and still pass the casual observer as a fairly clean sample.

TESTING OATS FOR VIABILITY

Standard Germination for oats 95 per cent.

Sampling: If taking a sample for germination from a bin, do not take it from one place, but mix up thoroughly 
several scoopfuls taken from different parts of the bin, then from this take a small sample and pick out at random 100 grains. Place these in germinating apparatus as described on page $6 \mathrm{I}$.

Moisten daily and keep at temperature of $50^{\circ}$ to $90^{\circ} \mathrm{F}$. Germination should begin in three days. As soon as the radicle is $\frac{1}{4}$ in. long the grain has germinated.

Remove all sprouted grains daily mutil germination ceases. Then by counting the number which failed to sprout and subtracting this from 100, you have the per cent of germination.

\section{BARLEY}

\section{CLASSIFICATION OF SPECIES AND VARIETIES.}

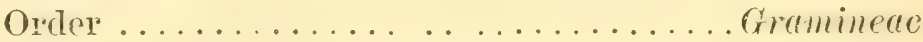

Genus ...................... Hordeum

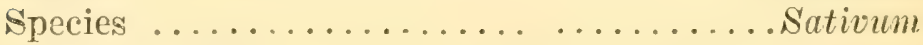

Cultivated barleys include a number of types, or races which by some are considered as sub-species and classified as follows:

1. Two-rowed barley....Hordcum sativum distichon

2. Four-rowed barley.... Hordeum sativum vulgare

3. Six-rowed barley. Hordeum satimm hexastichon

The two-rowed barleys commonly grown are characterized by their large plimp grain, and amongst these are found the best varieties for malting purposes.

The four-rowed and six-rowed barleys include the "naked" or "hulless" varieties.

In the six-rowed barleys the grains are smaller and generally inferior in quality to either of the others.

The four and six-rowed varieties are generally most prolific and are most commonly grown in this country for feeding purposes. 
The varieties of barley are numerous but only a comparatively few are grown in the United States.

Carefully examine samples of each of the abore trpes of barley, including samples of both black and white "hulless" barley.
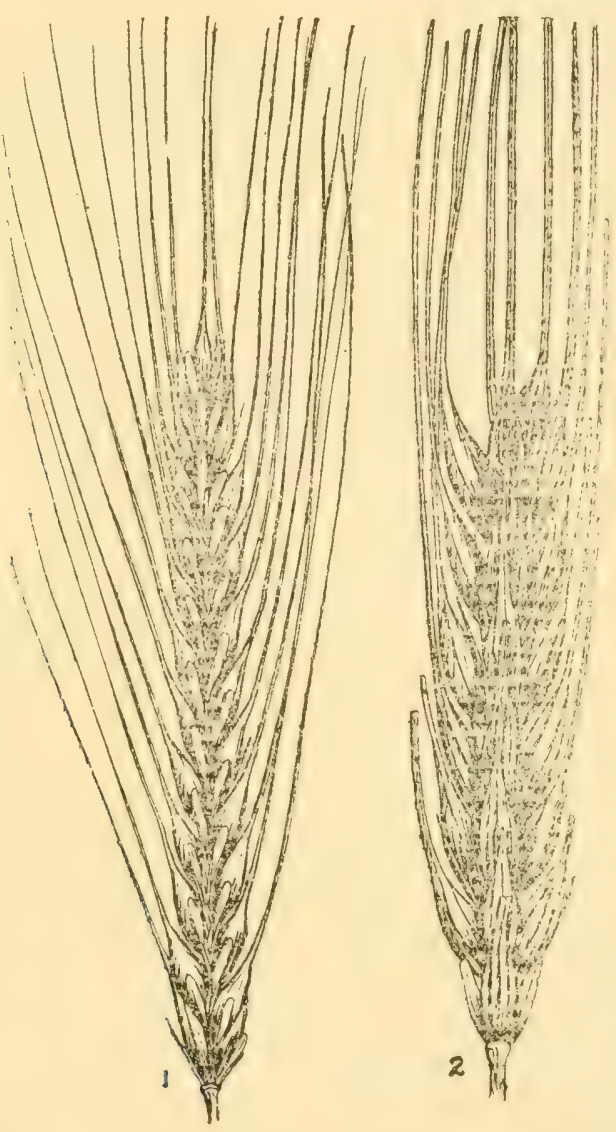

\section{Plate 15}

Types of barley spikes. No. 1. two-rowed brewing barley; No. 2, six-rowed hulless barley.

Make drawings from a spike of each type, showing the imbricated view.

Note that the grain of ordinary barley is tightly en- 
closed by the flowering glume, called the "hull" while in hulless barless the flowering glume and palet do not adhere closely and the grain is free.

In this respect hulled barley is comparable to oats and hulless to wheat.

Typical samples in the spike and of the threshed grain are provided. Carefully describe both the spike and grain of one or more samples each of the principal types of barley, as the two, four and six-rowed barlevs, and black and white hulless barleys.

The characteristics are obvious enough so that with a little careful comparison there should be no trouble in finding the proper adjective in the descriptive list.

Use the Outline for describing barleys, flling it out carefully.

\section{TERMS FOR DESCRIBING CHARACTERS}

\section{SPIKE}

1. $\left\{\begin{array}{l}\text { Two-rowed (Pl. 15, Fig. 1) } \\ \text { Four-rowed } \\ \text { Six-rowed (Pl. 15, Fig. 2) }\end{array}\right\} \begin{aligned} & \text { This refers to the number of } \\ & \text { rows of grain on the spike. }\end{aligned}$

2. $\left\{\begin{array}{l}\text { Awned } \\ \text { Partly awned } \\ \text { Awnless }\end{array}\right.$

3. Length (inches)

4. $\left\{\begin{array}{l}\text { Open (PI. 15, Fig. 1) } \\ \text { Compact (Pl. 15, Fig. 2) } \\ \text { Crowded }\end{array}\right\} \begin{aligned} & \text { Has reference to how close- } \\ & \text { ly or far apart the spikelets } \\ & \text { are on the racis. }\end{aligned}$ Shape

1. $\left\{\begin{array}{l}\text { Tapering toward tip } \\ \text { Tapering both ways } \\ \text { Uniform }\end{array}\right\} \begin{aligned} & \text { fhen out. } \\ & \text { are more oppressed than those at } \\ & \text { middle }\end{aligned}$

2. $\{$ Tip acute (Pl. 15, Fig. 1) $\}$

(Tip blunt (P1. 15, Fig. 2) Terminal spikelet well filled out

3. $\{$ Base abrupt \{

4. Sterile Spikelets, 1, 2, 3, etc. 
Color

1. $\left\{\begin{array}{l}\text { Whitish } \\ \text { Yellowish } \\ \text { Yellowish brown } \\ \text { Brown } \\ \text { Black }\end{array}\right.$

\section{AWNS}

(Long (Length 5 inches or more)

1. Medium (Length 3 to 5 inches)

(Short (Length less than 3 inches)

2. $\left\{\begin{array}{l}\text { Parallel (Pl. 15, Fig. 2) } \\ \text { Spreading (Pl. 15, Fig. 1) }\end{array}\right\} \begin{aligned} & \text { Refers to the relative posi- } \\ & \text { tion of the awns to the } \\ & \text { head. }\end{aligned}$

3. $\left\{\begin{array}{l}\text { Deciduous } \\ \text { Partly deciduous (Pl. 15, Fig. 2) } \\ \text { Persistent (Pl. 15, Fig. 1) }\end{array}\right\}$

This refers to the drop ping of the awns at malurity. The awns all drop off on some varieties while on others they are very

Color persistent.

1. $\left\{\begin{array}{l}\text { Whitish } \\ \text { Yellowish } \\ \text { Brownish } \\ \text { Black }\end{array}\right.$

\section{SPIKELET}

(This is not a spikelet in the botanical sense, but really a mesh of three spikelets.)

1. Number grains, $1,2,3$ (number of grains per spikelet).

2. Number of sterile flowers (Refer's to sterile flower's in a spikelet).

Size

1. $\left\{\begin{array}{l}\text { Broad (Pl. 16, Fig. 3) } \\ \text { Medium } \\ \text { Narrow (Pl. 16, Fig. 2) }\end{array}\right\} \begin{aligned} & \text { This depends largely on the shape } \\ & \text { of the grain and how well it is } \\ & \text { developed. }\end{aligned}$

Outer Glume (In barleys, these are very narrow and pointed.)

1. $\left\{\begin{array}{l}\text { Awned (Pl. 16, Fig. 3) } \\ \text { Awn pointed } \\ \text { Awnless (Pl. 16, Fig. 4) }\end{array}\right\} \begin{aligned} & \text { The outer or empty glume } \\ & \text { should not be confused with } \\ & \text { the flowering or seed bearing } \\ & \text { glume. }\end{aligned}$ 

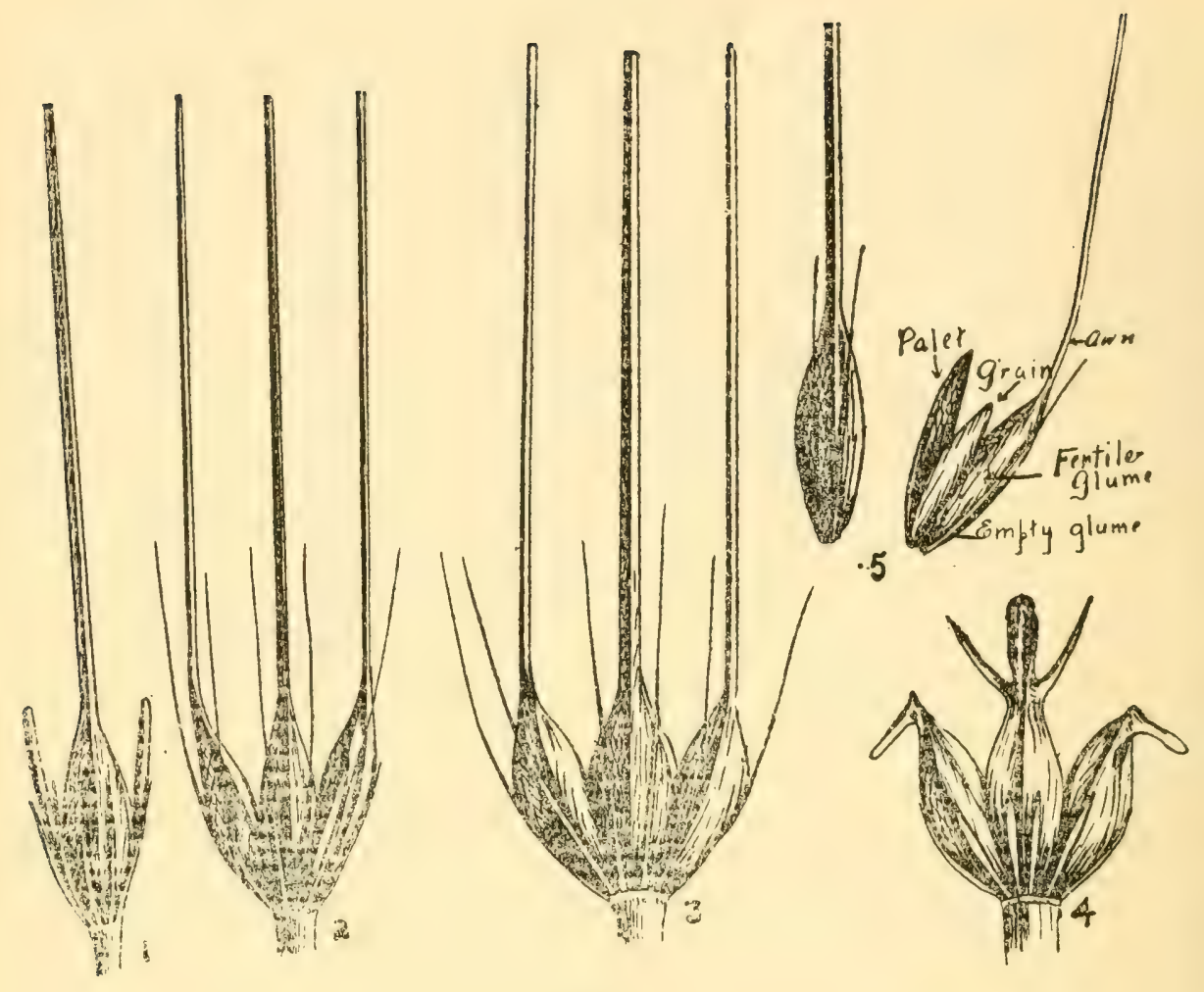

Plate 16

Types of barley spikelets. No. 1, spikelet from two-rowed barley; No. 2 , spikelet from six-rowed barley; No. 3 , a six-rowed hulless barley; No. 4 , a white hulless and awnless barley; No. 5 , shows a barley spikelet torn apart.

GRAIN

1. $\left\{\begin{array}{l}\text { Enclosed in flowering glume } \\ \text { Free (naked) }\end{array}\right\}$
This is the distinguishing characteristic between the naked or hulless barley and the ordinary kind. In the latter the grain is so tightly enclosed that it is not freed in threshing.

2. $\left\{\begin{array}{l}\text { Hard } \\ \text { Medium } \\ \text { Soft }\end{array}\right\} \begin{aligned} & \text { This point is most easily determined by biting or } \\ & \text { cutting the grains and comparing with standare } \\ & \text { samples }\end{aligned}$ Shape

1. $\left\{\begin{array}{l}\text { Long } \\ \text { Medium } \\ \text { Short }\end{array}\right\} \begin{aligned} & \text { Different varieties of barley show considerable varia- } \\ & \text { tion in size and ratio of length to diameter. Pick } \\ & \text { out about six typical kernels to examine for these } \\ & \text { points. }\end{aligned}$ 

2. $\left\{\begin{array}{l}\text { Thin } \\ \text { Medium } \\ \text { Plump }\end{array}\right.$
3. $\left\{\begin{array}{l}\text { Flat-cheeked } \\ \text { Plump-cheeked } \\ \text { Angular-cheeked }\end{array}\right\}$
The cheek is that portion of the grain on either side of the suture.
4. $\left\{\begin{array}{l}\text { Pointed at tip } \\ \text { Blunt at tip }\end{array}\right\}$
The tip of the kernel is opposite the germ end.
5. $\left\{\begin{array}{l}\text { Pointed at base } \\ \text { Blunt at base }\end{array}\right\}$
The base of the kernel is the germ end.

\section{Crease}

1. $\left\{\begin{array}{l}\text { Deep } \\ \text { Medium } \\ \text { Shallow }\end{array}\right\}$ Cut cross sections of several typical grains.

Cross-section

1. $\left\{\begin{array}{l}\text { Horny } \\ \text { Dull } \\ \text { Starchy }\end{array}\right.$

This point is determined by making cross seetions and examining carefully. Where only part of the grains show one characteristic, and the rest some other, the per cent of each kind should be expressed.

When Seed is Enclosed

(When the grain is enclosed in the glume, not "hulless."

1. $\left\{\begin{array}{l}\text { Rounded (dorsal side) } \\ \text { Medium } \\ \text { Flat }\end{array}\right\} \begin{aligned} & \text { Has reference to the shape of the } \\ & \text { dorsal side of the grain }\end{aligned}$

2. $\left\{\begin{array}{l}\text { Strongly nerved } \\ \text { Medium } \\ \text { Obscurely nerved }\end{array}\right\}$

The barley grain is fine nerved on the back. The prominence of these nerves varies greatly with difference barleys.

\section{Color}

1. $\left\{\begin{array}{l}\text { Whitish } \\ \text { Yellowish } \\ \text { Brownish }\end{array}\right.$

When Seed is Free (see Fig. - Hulless barleys).

Color

1. $\left\{\begin{array}{l}\text { Black } \\ \text { Purple } \\ \text { Purplish } \\ \text { Brown } \\ \text { Yellowish } \\ \text { Whitish }\end{array}\right\}$

When black barleys are fully matured, they are purplish black in color, but when cut very green they are often a yellowish white in color, with only a tinge of purple. 
OUTLINE FOR DESCRIBING BARLEYS

Variety Name

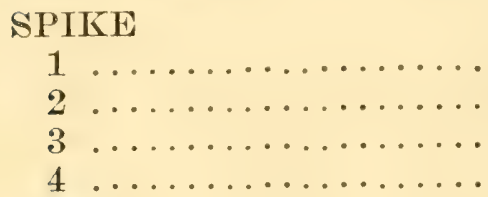

Shape

1.

2

3

4

Color

$1 \ldots \ldots \ldots \ldots \ldots$

AWNS

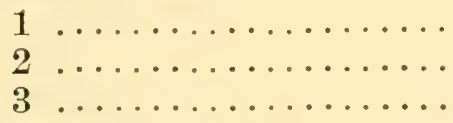

Color

1

SPIKELET

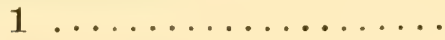

2

Size

1

Student's Name
Number of Sample...

Outer Glume

$1 \ldots \ldots \ldots \ldots \ldots$

GRAIN

$1 \ldots \ldots \ldots \ldots \ldots \ldots$

2

Shape

1

2

3

4

5

\section{Crease}

1

\section{Cross-section}

1

When Seed is Enclosed

Dorsal Side

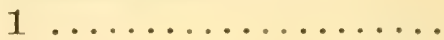

2

When Seed is Free

Color

$1 \ldots \ldots \ldots \ldots \ldots \ldots$

\section{EXAMINING AND GRADING BARLEYS.}

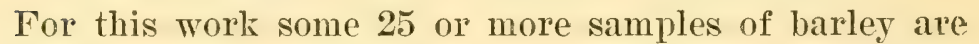
provided, covering all grades.

In judging barley from the brewer's standpoint, only good unbleached samples can be used, while from a feeder's standpoint a slight discoloration would be no objection.

The price of white barley is governed by the brewing qualities of the grain. Any discoloring or bleaching disqualifies it for this purpose.

A few points to be observed in grading barleys are as follows: 
Color: White barleys should be a clear, light color with no tint of yellow or brown.

Bleaching and discoloring caused from exposure to weather is probably the most common cause of injury to white barleys. Bleaching not only disqualifies barley for malting purposes by injuring the color of the product, but the wetting and drying which the grain is subjected to when bleached, injures its malting properties.

Black barleys when fully matured are usually a blueblack, but if harvested before fully matured, many of the grains will be brownish, with varying degrees of purple or blue, shading to almost black.

Texture: The texture of barleys varies from quite hard, and horny, (vitreous in appearance) to a crumbly texture, white and very starchy.

A good way to examine both the texture and hardness of a barley at the same time is to bite several grains in two. The difference in hardness and texture is directly correlated with the variation in proteid content. The very soft and starchy barleys contain the least proteids, about 8 per cent or 10 per cent, while barleys with a hard, horny texture, and usually vitreous appearance, sometimes contain as high as $\mathbf{1 5}$ per cent proteids.

Brewing Qunlities: German brewers generally prefer barleys of very low proteid content, from 7 per cent to 9 per cent, claiming that barleys containing a high per cent of proteids not only give a less per cent of extract, but a beer subject to turbidity. However, American brewers are using with good success, many western and northern barleys containing as high as 12 per cent to 14 per cent proteids.

The two-rowed barleys are generally known as "brewing barleys" and in the past have been preferred by many brewers, especially in Europe, but most American barleys are of the six-rowed type, and American brewers do not 
seem to make auy discrimination in favor of two-rowed barleys.

\section{BARLEY INSPECTION RULES*}

To. 1 Barley shall be sound, plump, bright, clean and free from all other grain.

No. 2 Barley shall be of healthy color, not sound enough and plump enough for No. 1, reasonably clean and reasonably free from other grain.

No. 3 Barley shall include slightly shrunken and otherwise slightly damaged barley not good enough for No. 2.

No. 4 Barley shall include all barley fit for malting jurposes not good enough for No. 3.

No. 5 Barley shall include all baxley which is badiy damaged or for any reason is unfit for maiting purposes, except that barley which has been chemically wenter sinall not be graded at all.

Black Parley. The grades Nos. 1, 2, 3 and 4 Black Barey shail conform in all respects to grades Yos. $1,2,3$ and 4 Frrley, except they shall be of the black rarietiess of barley.

In examining and grading barleys the brewing and feeding equlities should be kept in mind. Note with care the color, texture, brewing and feeding qualities of each sample. lieport on these points with the grade of the sample, after the following manner:

\begin{tabular}{c|c|c}
\hline NO. SAMPLE & GRADE & REMARKS \\
\hline 2 & 3 & Plump but quite bleached; good feeding value. \\
\hline
\end{tabular}

TESTING BARLEY FOR PURITY AND VIABILITY.

In testing barley for Purity and Germination, follow the directions given for oats.

\footnotetext{
*Rules adopted by the Board of Railroad and Warehouse Commissioners for the inspection of grain at Chicago.
} 


\section{HAY PLANTS}

The following outline is used in the study of common cultivated grasses and millets. By following the outline, one's attention is called to the distinguishing characteristics of each kind, giving not only a means of identification, but a good knowledge of the grass.

\section{OUTLINE FOR DESCRIBING GRASSES.}

THE STEM AND LEAVES.

Height

Color-Stem

Color-Leaves

Number of leaves

\section{HEAD}

Awned or awnless

Panicled, compact or spiked

Size-(Give length and diameter)

Color-Awns

Color-Chaff

\section{ROOT}

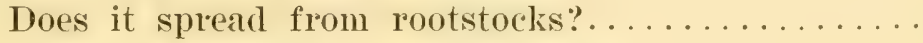

Is it a sod forming or bunch grass?.

\section{EXAMINATION OF GRASS SEEDS}

Size-

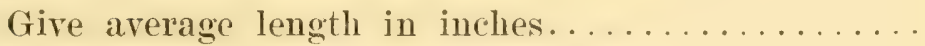
Color-

General color

General Notes-

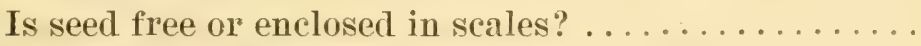

Weight per bushel

Amount sown per acre

Vitality

Drawings-Make drawing from comrex side-Make drawing of cross section. 


\section{HAY AND STRAT INSPECTION RULES.}

The following are the rules and regulations adopted by the Chicago Board of Trate for the inspection of Hay and Straw:

Choice Timothy Пay.-Shall be Timothy not mixed with over one-twentieth other grasses, properly cured, bright natural color, sound and well baled.

No. 1 Timothy Hay.-Shall be Timothy not more than one-fifth mixed with other tame grasses, properly cured, good color, sound and well baled.

No. 2 Timothy Hay.-Shall include Timothy not good enough for No. 1, not over one-third mixed with other tame grasses, sound and well baled.

No. 3 Timothy Hay. - Shall include all Hay not good enough for other grades, sound and well baled.

No. 1 Clover Mixed Hay.- Shall be Timothy and Clover mixed, with at least one-half Timothy, good color, sound and well baled.

No. 2 Clover Mixed Hay- - Shall be Timothy and Clover mixed. with at least one-third Timothy, reasonably sound and well baled.

No. 1 Clover Hay.-Shall be medium Clover, not over one-twentieth other grasses, properly cured, sound and well baled.

No. 2 Clover Hay.-Shall be Clover, sound, well baled, not good enough for No. 1.

No Grade Hay--Shall include all Hay badly cured, musty stained, threshed, or in any way unsound.

Choice Prairie Hay.-Shall be Upland Hay, of bright color, well cured, sweet, sound and reasonably free from weeds.

No. 1 Prairie Hay.-Shall be Upland and may contain one-quarter Midland of good color, well cured, sweet, sound and reasonably free from weeds.

No. 2 Prairie Hay.-Shall be Upland of fair color, or 
Midland of good color, well cured, sweet, sound and reasonably free from weeds.

No. 3 Prairie Hay.-Shall be Midland of fair color, or slough of good color, well cured, sound and reasonalyy free from weeds.

No. 4 Prairie Hay.-Shall include all Hay not good enough for other grades, and not caked.

To frade Prairie Hay.--Shall include all Hay not good enough for other grades.

No. 1 Straight Rye Straw.-Shall be in large bales, clean, bright, long Rye Straw, pressed in bundles, sound and well baled.

No. 2 Straight Rre Straw.- Shall be in large bales, loug Rye Straw, pressed in bundles, sound and well baled, not good enough for No. 1.

Tangled liye Straw.- Shall be reasomably clean Rye Straw, good color, sound and well baled.

Wheat Straw.-Shall be ieasonably clean Wheat Straw, sound and well baled.

Oat Straw.-Shall be reasonably clean Oat Straw, soind and well baled.

\section{IDENTIFICATIOX OF CLOVER ANI) GRASS SEEDS}

There is no work which requires more areful attention $01^{\circ}$ is more raluable than the identification of grass and clover seeds and separating then from their adulterants.

Wor eximining the seeds a small tripon lens is rery nseful. Use the following artificial key which is not intended to describe the seed but simply calls four attention to the most prominent characteristics of each variety.

CLOVER SEEDS

Key for Identification

1. Seed Free (Not enclosed in pod.)

(A) Seed bean shaped.

Color ; pinkish, $\frac{1}{8}$ in. long......... Crimson Clover 
Color; mostly sellow; large seeds are kidney shape ...................... . . . . .

(Turkestan alfalfa is same but slate colored.)

Color; dark yellow to brown ........ Yellow Trefoil

(B) Seed Oral-oblong.

Color; yellow, seed notched near one end...

.Bokarah Clorer

(C) Seed heart shaped.

Color; yellow to brown ............ White Clover

Color; dark green to black...........Alsike Clorer

(D) Seed somewhat triangular.

Color; yellow to brownish ........... Red Clover

2. Seced Enclosed in Pod.

(A) Pod; large and corrugated, $\frac{1}{4}$ in. long.

Color; brown, seed bean shaped ......... Sainfoin

(B) Pod; whitish, $\frac{1}{8}$ in. long.

Color; sellow, seed oral, notched near end....

(C) Pod; brown, $\frac{1}{8}$ in. long.

Yellow Sweet Clorer

Color; dark browu, seed mottled......Japan Clorer GRASS SEEDS

\section{Key for Identification}

Seeds distinctly awned.

Seed $\frac{1}{1}$ in. or more in length.

Ver's hairy or pubescent, flat, thin.. Meadow Fox-tail

Awns attached at tip .......... Annual Rye Grass

Awns long, twisted, attached near base..... Tall Meadow oat-grass

Seeds less than $\frac{1}{4}$ in. long.

Small brownish seed ............ Sheep Fescue Short awned or awn pointed.

Small dark brown seeds, very rough near tip.... .Crested Dog's-tail

$\frac{3}{8}$ in. long, smooth, light colored....... Wheat grass

$\frac{1}{4}$ in. or less in length ............. Orchard grass Awnless.

$\frac{3}{8}$ in. long or thereabout, nerres rery prominent. .

Brome Grass 
About $\frac{1}{1}$ in. long, / Obscurely, 3-nerved, Perennial Rye grass light brown ... Strongly, 5-nerved, Meadow fescue $\frac{1}{8}$ in. long or less.

Keel rough, saw-like ..............Red Top Keel not commonle rough .... Kentucky Bluegrass seed free from glumes, polished.

Very small 1/32 in. length, polished ..... Timothy Hard, smooth seeds, about $\frac{1}{4}$ in. long...Johnson grass MILLET SEEDS

Ken for Identification

Seeds ovoid, flattened on one sirle and enclosed in glumes; usually shiny, $1 / 10$ in. to $1 / 20 \mathrm{in.}$ in length.

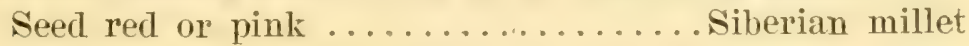

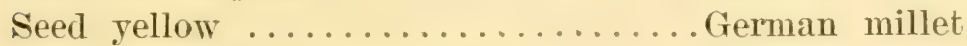

Seed mostly black .............. Hungarian grass Seed dull brown, outer covering loose and rough .Japanese barnyard millet

Seed brownish-rellow (Tarieties of this millet are white and others red) ........... Hog millet

\section{APPARATUS FOR GERMINATING SEEDS}

Cremination tests are ensily made, even mith the simplest apparatus.

I sees incubator is enerally made on the plan of an oren, double walled and often covered with asbestos. The space between the donble walls mar be filled with water. This is usually heated with a gas jet or lamp so arranged that a fairly constant temperature can be maintained.

The seeds are placed in tiars, between moist blotting papers and kept in the incubator which is closed up in order to produce a moist atmosphere, until germination is complete. The best temperature for germinating most seeds is between $80^{\circ}$ and $90^{\circ} \mathrm{F}$.

\section{Home Made Germinator.}

One of the simplest and most practical germinators can 
be made by taking two common dinmer plates, and placing in the bottom of one, two or three layers of filter paper or other absorbent and thoroughly wetting it. Place the seeds to be tested on top of this. If the seeds are large as corn or wheat you may cover them with blotting paper or a cloth, though this is not necessary. Small seeds, such as clover or grass, do better if not covered.

Now invert the second plate over the first, being careful that the edges touch evenly. This makes a moist chamber, and gives the most favorable conditions for germination.

Similar moist chambers may be fixed up by using any shallow bucket or pan having a cover, or tin or wooden boxes may be used such as tobacco and cigar boxes, all of which when used properly will give satisfactory results.

\section{DERMINATION OF WEIGHT PER BUSHEL}

Grain testers are usually made in three sizes, pint, quart and two quart. When the measure is properly filled with grain and hung on the balance, the number of pounds the grain will weigh per bushel can be directly read.

The greatest care must be exrreised in filling the mestsure. The grain should not be shaken or pressed down but allower to fall as loosely as possible into the tester. Do not dip the grain up with the measure, but take the measure in both hands and force it bottom down until the top. is level with the grain, then scoop the grain in with the han r., allowing it to fall as loosely as possible. Then being cariful not to press or shake down the orain, stroke the (op) with a straight edge, and hang on the balance.

A little practice will enalse one to do fairly accurate work with the tester.

Practice work with tester.

'Try taking duplicate samples mutil you can get the same results every time.

Fill the sampler in various ways such as dipping it into 
the grain, or shaking and pressing the grain down a little after the tester is filled, and compare weights with those obtained when tester is properly filled.

\section{TEST FOR MOISTURE IN GRAIN}

Use samples of corn of various grades, and kept under different conditions, such as corn too wet to grade, corn kept in open crib since husking, corn kept in dry seed room, etc. Also use samples of oats, wheat and barley.

Sampling: After mixing up your sample carefully, take about two ounces and grind in a fine coffee mill, running it through several times, reducing as fine as possible. Then take a 1 gram sample and dry in water oven to constant weight. The per cent of moisture is found by dividing the difference between weight of original sample and dry sample, by weight of dry sample. 


\section{TABLE OF GRAIN WEIGHTS PER BUSHEL}

LBS. PER Bu.

LBs. PER Bu.

Alfalfa ..........60

Kentucky Blue Grass...14

Alsike ..........660

Meadow Foxtail ...... 7

Barley ...........48

Meadow Fescue .......14

Beans, all ........660

Buckwheat ........52

Meadow Grass, Rough

Broom Corn ........46 Stalked .........14

Brome Grass ........14

Millet ............50

Blue Grass, Kentucky...14

Oats ...............32

Blue Grass, English....14

Orchard Grass ........14

Cane ............50

Pearl Millet .......56

Clover, Alsike .......60

Peas, Field or smooth

Clover, Red .......660 garden .........6.60

Clover, White Dutch...660

Peas, wrinkled ......56

Corn ............56

Peanuts .........24

Corn, on ear.........70

Cow Peas .........60 60

Pencilaria .........56

Creeping Bent Grass....20

Crested Dogtail ......21

Potatoes, Irish, good

English Blue Grass.....14 measure ........660

Potatoes, sweet ......50

Rape ............60

English Rye Grass......14

Emmer ............40

Red Top ...........14

Fescue, Hard ........14

Red Clover ........60

Fescue, Sheep ........14

Rve ............56

Flax ..........56

Rye Grass, English....24

Rye Grass, Italian. . . . .24

Hemp ...........44

Speltz or Emmer......40

Hungarian Millet ....448

Sweet Vernal ........10

Japanese Millet ......40

Timothy ..........45

Johnson Grass .......25

Vetches or Tares.....60

Kaffir Corn .........50

Wheat ..........60

White Clover .......60 

LIBRARY OF CONGRESS

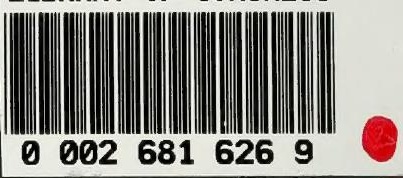

